\title{
UNCERTAINTY QUANTIFICATION OF CONCRETE UTILIZED IN DRY
}

\section{CASK STORAGE}

\author{
A Thesis \\ by \\ RYAN PATRICK KELLY
}

Submitted to the Office of Graduate Studies of

Texas A\&M University

in partial fulfillment of the requirements for the degree of

MASTER OF SCIENCE

Approved by:

Chair of Committee, Pavel V. Tsvetkov Co-Chair of Committee, Sunil S. Chirayath

Committee Members, John W. Poston

Michael B. Pate

Head of Department, Yassin A. Hassan

May 2013

Major Subject: Nuclear Engineering

Copyright 2013 Ryan Patrick Kelly 


\begin{abstract}
The objective of this thesis is to quantify the uncertainty in radiation dose rate estimates outside of a used fuel dry cask storage unit due to the parametric variability of concrete composition and density. This requires the selection of a limited number of concrete compositions from a standardized database and the development of a reference dry cask model, which can be used to estimate dose rate from neutrons and gamma rays. The model was developed using the Monte Carlo N-Particle code, with reference data from a used fuel assembly source provided by operators at Comanche Peak Nuclear Power Plant and geometry based on the Holtec HI-STORM 100S used fuel dry cask storage system. The majority of the model was then fixed and the dose rates were compared when different concrete compositions at their nominal densities were substituted. Additional cases compared results for different concrete compositions at a fixed density, different densities for a fixed composition, and a different gamma energy source term for fixed compositions and densities.

The comparison of model results confirmed that the parametric variability of concrete composition is a major source of uncertainty for dry cask dose rates. While precise results depend on the compositions compared, general trends cam be identified. The majority of the dose in all cases, typically $70 \%$, depended on gamma rays produced by the fission products. Density was the dominant factor in determining the dose rate, as expected. Composition variation while density was held fixed, however, indicated that the precise composition has a large effect on the dose rates produced by neutrons and
\end{abstract}


gamma rays produced by neutron capture, on the order of $70 \%$ or higher for test cases, with only a moderate impact on the dose rate from gamma rays produced by other sources, on the order of $20 \%$ for test cases. Alterations to the gamma energy spectra produced by additional decay uniformly lowered the dose, and did not significantly change comparative concrete performance. Overall results indicate that, due to the lack of standardization of concrete poured on site, additional safety factors may be necessary due to variation of shielding effectiveness. 


\section{DEDICATION}

For my family, thank you for all of the support, and for being there when I needed someone to listen. 


\section{ACKNOWLEDGEMENTS}

I would like to thank my committee co-chairs, Dr. Tsvetkov and Dr. Chirayath, and my committee members, Dr. Poston and Dr. Pate, for their guidance and support throughout the course of this research.

Thanks also go to my friends and colleagues and the nuclear engineering department faculty and staff for making my time at Texas A\&M University a great experience.

Finally, I would like to thank the people that helped make this work possible, the operators at Comanche Peak Nuclear Power Plant that provided some of the key data and Evans Kitcher, who helped me develop the initial model that was used as the framework for this research. 


\section{NOMENCLATURE}

$\begin{array}{ll}\text { ANS } & \text { American Nuclear Society } \\ \text { ANSI } & \text { American National Standards Institute } \\ \text { BWR } & \text { Boiling Water Reactor } \\ \text { CPNPP } & \text { Comanche Peak Nuclear Power Plant } \\ \text { ENDF } & \text { Evaluated Nuclear Data File } \\ \text { MCNP } & \text { Monte Carlo N-Particle code } \\ \text { MPC } & \text { Multi-Purpose Canister } \\ \text { NBS } & \text { National Building Specification } \\ \text { NRC } & \text { Nuclear Regulatory Commission } \\ \text { PWR } & \text { Pressurized Water Reactor } \\ \text { SS } & \text { Stainless Steel } \\ \text { UNF } & \text { Used Nuclear Fuel } \\ \text { VISED } & \text { MCNP Visual Editor } \\ \end{array}$




\section{TABLE OF CONTENTS}

Page

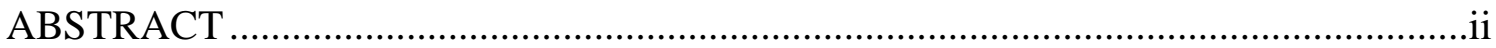

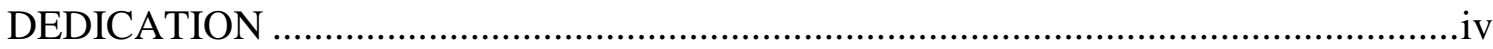

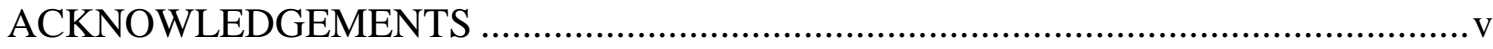

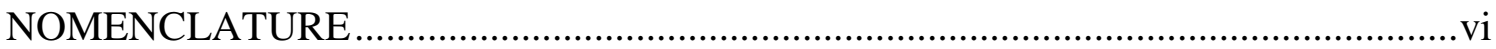

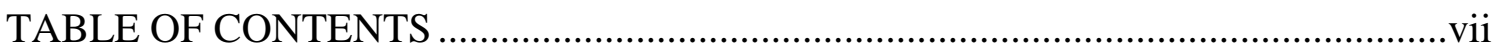

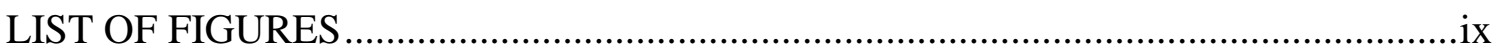

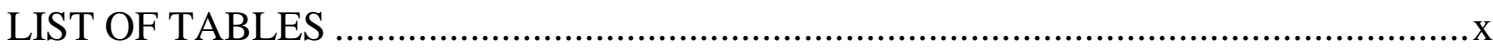

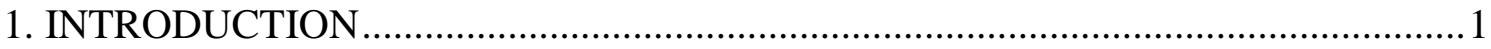

1.1 Current Status

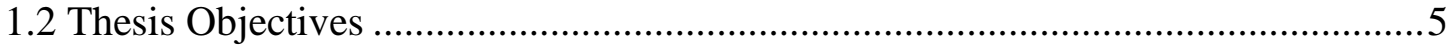

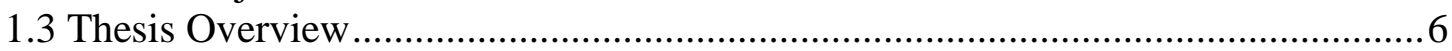

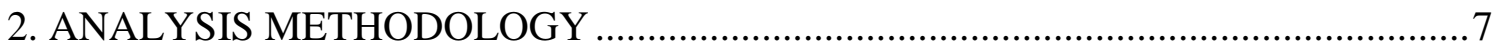

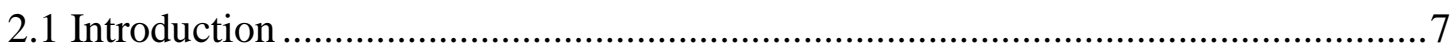

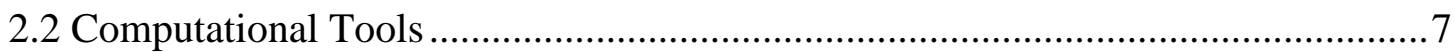

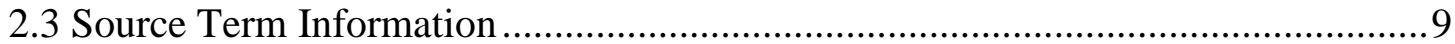

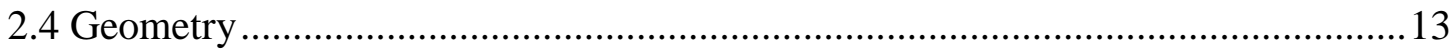

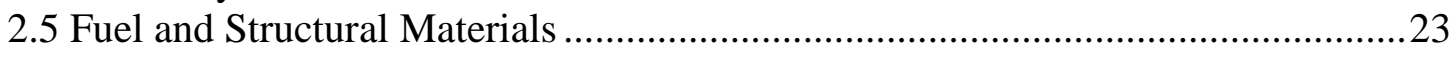

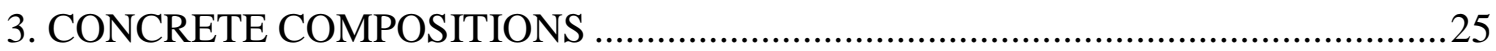

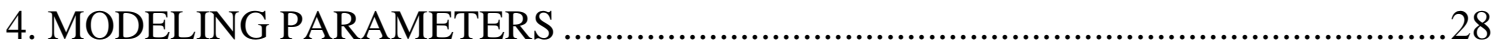

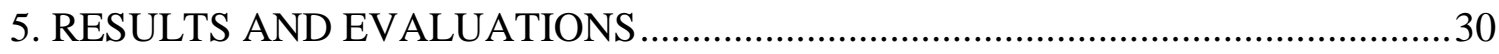

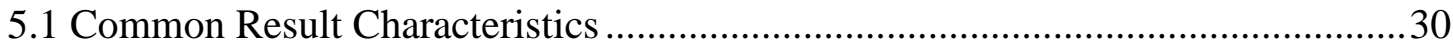

5.2 Results at Nominal Density and Composition ........................................................30

5.3 Comparison of Dose Components for Various Compositions at a Fixed Density 
5.4 Comparison of Dose Components at Various Densities for a Single

Composition

5.5 Comparison of Three-Years-Cooled and Five-Years-Cooled Results ...................45

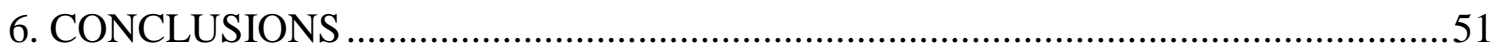

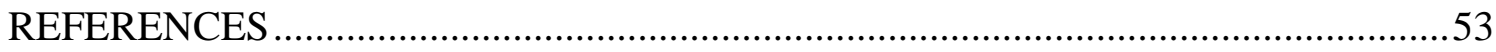




\section{LIST OF FIGURES}

Page

Figure 1. Schematic of HI-STORM 100S Cask ${ }^{15}$ 15

Figure 2. VISED rendering of a Westinghouse $17 \times 17$ fuel assembly in the Boral sheath.

Figure 3. VISED rendering of MPC-32 contained in HI-STORM 100S Version B (218).

Figure 4. VISED rendering of the central plane of the fueled region.

Figure 5. Source particle distribution in the fueled regions.

Figure 6. Axial positions of single cask ring tallies.

Figure 7. Equivalent dose rate from fission products as a function of height for various densities of standard concrete.

Figure 8. Equivalent dose rate from activated structures as a function of height for various densities of standard concrete

Figure 9. Equivalent dose rate from neutrons as a function of height for various densities of standard concrete.

Figure 10. Equivalent dose rate from gammas produced by neutron capture as a function of height for various densities of standard concrete.

Figure 11. Equivalent dose rate from fission products as a function of height for three-years-cooled and five-years-cooled fuel with standard concrete.

Figure 12. Equivalent dose rate from fission products as a function of height for three-years-cooled and five-years-cooled fuel with NBS 03concrete.

Figure 13. Equivalent dose rate from fission products as a function of height for three-years-cooled and five-years-cooled fuel with NBS 04 concrete.

Figure 14. Equivalent dose rate from fission products as a function of height for three-years-cooled and five-years-cooled fuel with Hanford concrete. 


\section{LIST OF TABLES}

Table 1. Gamma Source Term after Three-Year Decay for Each Used Fuel Assembly

Table 2. Gamma Source Term after Five-Year Decay for Each Used Fuel Assembly

Table 3. Activation Product Co-60 Source Term after Three-Year Decay for Each Set of Used Fuel Assembly Components

Table 4. Neutron Source Term for Each Used Fuel Assembly

Table 5. Compositions Used in the HI-STORM Cask and MPC-32 24

Table 6. Concrete Composition Details 27

Table 7. Equivalent Dose Rate of a Single Cask Shielded by Standard Concrete 32

Table 8. Equivalent Dose Rate of a Single Cask Shielded by NBS 03 Concrete 33

Table 9. Equivalent Dose Rate of a Single Cask Shielded by NBS 04 Concrete

Table 10. Equivalent Dose Rate of a Single Cask Shielded by Hanford Concrete (Dry) 35

Table 11. Equivalent Dose Rate from Fission Products for Various Compositions 37

Table 12. Equivalent Dose Rate from Activated Structures for Various Compositions..... .38

Table 13. Equivalent Dose Rate from Neutrons for Various Compositions 39

Table 14. Equivalent Dose Rate from Gammas Produced by Neutron Capture for Various Compositions 


\section{INTRODUCTION}

\subsection{Current Status}

The storage of used nuclear fuel has become an increasing concern in recent years, particularly in the United States, due to the lack of a permanent repository. UNF is defined as all fuel that has been withdrawn from a reactor following irradiation, including intact, non-defective fuel assemblies, failed fuel assemblies, segments of fuel rods or pieces derived from irradiated fuel rods, and the structural components of irradiated assemblies ${ }^{1,2}$. Early proposals for UNF management called for reprocessing, but due to the policy decisions and financial costs, this alternative has not been historically pursued for commercial nuclear fuel in the United States. After the withdrawal of funding and political support from the Yucca Mountain Repository Project, the failure to develop a deep geological repository, as required by the Nuclear Waste Policy Act of 1982, has required increased interim measures to be taken to store nuclear fuel, typically on site at active or decommissioned nuclear reactors, however, ongoing operation of nuclear power plants produces additional irradiated fuel at an annual rate over of over 2000 metric tons per year. Current US policy proposals indicate that the government will be involved in final disposal, either the anticipated deep geological disposal, or other proposed methods including sub-seabed disposal and disposal through in situ melting, however, the timeframe for these measures is still indefinite and proposals for a new UNF management agency indicate that interim storage measures will be necessary until this issue can be resolved. While some efforts 
have been made to consolidate UNF at monitored retrievable storage installations, the pace of these efforts requires storage to continue to be primarily on site.

The two main methods of interim irradiated fuel storage utilized in the United States are wet pool and dry cask storage. After removal from a reactor core, commercial fuel is moved to a UNF pool, where water is used to both shield workers and to provide convective cooling to the fuel, which remains highly radioactive and a large decay heat source. UNF is generally stored vertically in these pools, and capacities range from approximately 2000 to $5000 \mathrm{UNF}$ assemblies. Used fuel pool capacity is limited, however, and NRC predictions indicate that nearly 100 used fuel pools will have been filled to capacity by $2015^{3}$. In addition, packing arrangements and reliance on water for shielding create security and safety vulnerabilities in the events of accidents similar to the one that occurred at the Fukushima Daiichi plant, and the need to provide makeup water and pumping power adds to the economic costs ${ }^{4}$. There are also safety concerns for used fuel pools that are within reactor containment, particularly in older BWR designs, where issues with either the reactor or the used fuel pool can affect other systems. Overall, these concerns have prompted vendors to increase usage of dry cask storage systems.

Dry cask storage has been utilized since 1986. In order to expand the temporary storage options available to the utilities that are responsible for their UNF, the NRC allows the companies to transfer UNF to dry cask storage systems after at least one year has passed since the fuel has been removed from the core, which allows radioactive decay levels and heat production to drop to levels that allow safe handling and storage 
outside of an aquatic environment. A variety of dry cask storage system designs have been certified by NRC, including storage in both a vault and on an external pad. In addition, the casks themselves may be placed vertically or horizontally depending on the specific design. These cask systems must be designed to accommodate both the need to continually dissipate heat and the need to shield workers from gamma and neutron radiation dose. Dry cask storage is a mid-term solution. Licenses are typically issued for 20 years, and may not exceed forty years ${ }^{5}$. The overall lifetime of a typical dry cask storage unit is predicted to be 100 years based on design calculations. The material composition of the cask, particularly the concrete, is especially significant in shielding considerations due to its role in attenuating neutrons and gamma rays. Parametric variability of the concrete densities and composition is a concern in modern storage systems. This will become particularly important as utilities attempt to push for higher burnup levels ${ }^{6}$. This research is focused on investigating the sensitivity of dose rate levels outside of storage casks to specific concrete compositions and densities, particularly in casks exposed to the environment.

Previous research has been performed on the safety of dry cask storage. In particular, probabilistic risk assessments have been conducted to determine potential dangers due to accidents or failures ${ }^{7}$. The parametric variability of concrete and its impact, however, has not been sufficiently addressed, and the potential impact on dose rate levels is a serious consideration when determining the safety precautions that need to be taken, including the size of exclusion zones and the positioning of any security around the casks. Previous tests have addressed some of the potential impact of various 
concrete compositions in simplified situations, but have not taken into account density variations of a specific composition or the potential effects of cask structure ${ }^{8,9}$. Due to the tolerances in industrial processes, the potential for error, and the variety of commercial compositions available to plants, which typically add the concrete on-site due to the significant weight of the casks, some variance is expected. This research works to address some of these issues.

Concrete performance is determined by the microstructure of the material, which is controlled by the composition itself, curing conditions, mixing method and mixer conditions $^{10}$. The methodology used to determine the quality of the concrete is often referred to as the measurement of the efficiency of the mixture, and is controlled by the order the aggregate and water are introduced to a mixer, the type of mixer, and the specific duration and power of the mixing process. This process is not well standardized, however, making it difficult to consistently determine concrete properties. Variations of between 6 and $8 \%$ for key values, including water to fine element content, air content, and variations between aggregate particle sizes are considered acceptable for ordinary mixers of the same type that are adhering to the Peterson standard, and even high performance mixers allow sufficient variation that it is difficult to predict the exact composition and density of concrete. In addition, differences, for the same aggregate mixture, can be even larger for different models of concrete mixers, such as for a batch mixer that produces a large amount of concrete at once and a drum mixer that produces a continual flow of concrete. Even within the same batch, homogeneity of concrete can be an issue depending upon the methodology used. Current tests require samples of 
concrete homogeneity to be taken during discharge, and removal of concrete from a dry storage cask if the material composition is different from the expected value is not a feasible solution. While a limited set of standards have been proposed, even assuming that a standardized specification of concrete is utilized for a dry cask storage system, the current parametric variability of these compositions represent a relatively large uncertainty that requires larger safety factors.

\subsection{Thesis Objectives}

The objective of the thesis is to quantify the uncertainty in dose rate estimates outside of the UNF dry cask storage units due to the parametric variability of concrete composition and density. In order to accomplish this task, it was necessary to identify concrete compositions appropriate for use in shielding applications, including their expected densities, and to create a reference model based off of contemporary dry cask storage designs that will be utilized to determine both gamma and neutron equivalent radiation dose rate levels at a fixed distance from the cask. Three major aspects of this task were to compare a limited number of concrete compositions to determine the impact of a fundamental composition difference between commercial brands or specified standards, to compare these effects relative to the effects of density variations, particularly for those with a large uncertainty or density range, and to determine how additional decay time impacted these results by comparing a limited set of cases with altered gamma energy spectra to account for additional decay 


\subsection{Thesis Overview}

First a reference model based off of a contemporary dry cask storage design was developed to determine both gamma and neutron radiation dose rate levels at various distances from the cask. The model included the capability to handle gamma rays from activated structural materials in the assembly and the gamma rays produced by neutron capture in structural materials. While there is no standard dry cask storage design, due to the variety of approaches used, this model was based off of a Holtec design, the HISTORM 100S system, a NRC approved storage cask system ${ }^{11}$. Similar designs include the Westinghouse MC-10, NAC S/T, and CASTOR V/21. This system is comprised of a fixed number of fuel assemblies inside a basket and neutron shielding, called the MPC unit, which can be transferred between different types of container, and the HI-STORM over-pack itself, a steel structure designed to be filled with concrete on site that will serve as the shielding for the fuel assemblies during the interim storage. After developing the basic computational model of MPC and HI-STORM over-pack using MCNP code, a variety of concrete compositions appropriate for use in shielding were identified from databases, and then a set of four different types were selected for additional radiation transport simulations and comparison with basic model

simulations $^{12}$. Besides the basic comparison between the four composition types, separate studies to determine the effects of density changes of a composition, and of how additional decay time changing the spectrum of fuel source would influence shielding were also performed. 


\section{ANALYSIS METHODOLOGY}

\subsection{Introduction}

Studies were conducted to determine the impact of the concrete shielding utilizing high-fidelity computer models. Cask geometry and structural materials were based upon existing dry storage cask designs in use today. Variation of concrete parameters in this realistic model allow for accurate estimates of radiation dose rates and a detailed study of the associated uncertainties.

\subsection{Computational Tools}

To accurately model the complex, three-dimensional geometry of the dry cask storage system, the MCNP5.1.51 code was utilized ${ }^{13}$. MCNP is a general purpose Monte Carlo N-Particle code that can be used for coupled photon, neutron, and electron transport, as well as k-eigenvalue (criticality) calculations. The code is able to handle arbitrary, three-dimensional shapes through the use of geometric cells bounded by firstand second-degree surfaces, as well as fourth-degree elliptical tori. Point-wise nuclide cross sections are used. The code accounts for all potential neutron reactions, for incoherent and coherent scattering, the possibility of fluorescent emission after photoelectric absorption, and absorption in electron-positron pair production for photons. Thermal neutrons can be analyzed using both free gas and $S(\alpha, \beta)$ models. The general source cards used in MCNP were used to create a distributed source for each individual irradiated fuel assembly in the model, allowing for a reasonable approximation of the photon and neutrons produced by the assemblies. A neutron energy regime between $10^{-11}$ 
$\mathrm{MeV}$ and $20 \mathrm{MeV}$ for all radionuclides, as well as a photon energy regime from $1 \mathrm{keV}$ to $100 \mathrm{GeV}$, indicates that the program is capable of handling the energy range of the used fuel.

Monte Carlo methods, such as those used in MCNP, simulate individual particles, and then tally or record average results at a location specified by the user. These methods are successful in theoretically duplicating the statistical process. The central limit theorem indicates that, with a sufficient sample, the behavior of particles in a physical system should approach this average value. Monte Carlo methods only supply data specified in user requested tallies (detection points), not a complete solution throughout the phase space. However, it is generally better suited to solving complicated, threedimensional, time-dependent systems than deterministic calculations, which would be immensely difficult at this level.

The photon data was drawn from MCPLIB. The data in this library were derived from ENDF/B-IV, the Storm and Israel 1970 compilation, and the fluorescence data from Everett and Cashwell. The library does not contain momentum profile data. While expansions have been released for specific applications, MCPLIB is a stable data library that has remained unchanged since 1982 .

The neutron data was drawn from ENDF/B-VII. The ENDF library, or evaluated nuclear data file library, is the US standard that is updated by the Cross Section Evaluation Working Group annually, and version VII is the latest major update of the data. 
Photon and neutron flux-to-dose rate conversion factors utilized include the 1977 ANSI/ANS library, one of the standard sets of conversion factors used for shielding applications. These factors enable users to convert a calculated particle flux to the human biological equivalent dose rate. These are also the factors used by the Nuclear Regulatory Commission to determine dose rates.

\subsection{Source Term Information}

The gamma radiation source term per unit mass of uranium in the used fuel assembly for this project was provided by officials working at the CPNPP ${ }^{14}$. The data from this source term was then multiplied by the amount of uranium in each assembly to determine total assembly radioactivity levels. After this, the radioactivity level was appropriately decayed to a level of interest for dry cask storage. Multiple decay times (three-years-cooled and five-years-cooled) were tested to determine the impact of the source energy distribution upon the final results. This source was applied to each assembly inside the cask to approximate average assemblies that have reached the desired cooling level, and a tally multiplier FM card accounted for the total source strength. The source was evenly distributed within the fuel region to reduce computation time.

$\mathrm{A}^{60} \mathrm{Co}$-source term was also used to compute the dose rate generated by activated structural portions of the fuel assembly. Source term estimates for each portion of the assembly were determined from data recorded by operators at CPNPP. The particle source generated from this information was comprised of 50\% 1.173-MeV 
gamma rays and 50\% 1.332-MeVgamma rays in a distribution proportional to the source term.

Similar source term estimates were available for neutron emissions of used fuel assemblies, and these served as the basis for the neutron source term. The neutron source spatial distribution utilized the gamma distribution for the fuel, though with different tally multiplier FM cards to account for the total neutron source strength. The effects of an additional decay upon neutron sources, however, can be assumed to be negligible due to the very large long-lived nature of the neutron emitters. Therefore, these dose levels were only calculated for one decay level.

Based upon this data, results were developed for three-year-cooled and five-yearcooled assemblies. Table 1 summarizes the number of photons produced at a given energy level per assembly for fuel that has cooled for three years, while Table 2 summarizes this source term for fuel that has cooled for five years. Table 3 shows the total activity produced by each portion of the fuel assembly, which was used as the basis of the spatial distribution of the ${ }^{60} \mathrm{Co}$-source term and its magnitude. Finally, Table 4 shows the assembly neutron source term that was utilized for the cases for both threeyear-cooled and five-year-cooled fuel. These sources depend only on the fuel assemblies, and so were kept constant while the concrete compositions and densities were varied. 
Table 1. Gamma Source Term after Three-Year Decay for Each Used Fuel Assembly

\begin{tabular}{|c|c|c|c|}
\hline Energy [MeV] & Photons/sec & Energy $[\mathrm{MeV}]$ & Photons/sec \\
\hline $1.113 \mathrm{E}-03$ & $8.01 \mathrm{E}+10$ & 5.693E-01 & $2.50 \mathrm{E}+14$ \\
\hline $3.357 \mathrm{E}-02$ & $3.33 \mathrm{E}+12$ & $5.720 \mathrm{E}-01$ & $8.60 \mathrm{E}+04$ \\
\hline 3.549E-02 & $3.79 \mathrm{E}+12$ & 5.997E-01 & $5.12 \mathrm{E}+06$ \\
\hline $4.098 \mathrm{E}-02$ & $4.33 \mathrm{E}+12$ & 5.998E-01 & $0.00 \mathrm{E}+00$ \\
\hline $5.328 \mathrm{E}-02$ & $5.76 \mathrm{E}+05$ & $6.006 \mathrm{E}-01$ & $1.58 \mathrm{E}+13$ \\
\hline $7.570 \mathrm{E}-02$ & $4.55 \mathrm{E}+05$ & $6.047 \mathrm{E}-01$ & $1.58 \mathrm{E}+15$ \\
\hline $8.012 \mathrm{E}-02$ & $2.27 \mathrm{E}+13$ & $6.067 \mathrm{E}-01$ & $4.45 \mathrm{E}+12$ \\
\hline $9.848 \mathrm{E}-02$ & $1.01 \mathrm{E}+06$ & $6.103 \mathrm{E}-01$ & $7.54 \mathrm{E}+06$ \\
\hline $1.055 \mathrm{E}-01$ & $1.47 \mathrm{E}+03$ & $6.113 \mathrm{E}-01$ & $2.24 \mathrm{E}+06$ \\
\hline $1.170 \mathrm{E}-01$ & $2.48 \mathrm{E}+11$ & $6.120 \mathrm{E}-01$ & $1.44 \mathrm{E}+05$ \\
\hline $1.335 \mathrm{E}-01$ & $1.85 \mathrm{E}+14$ & $6.204 \mathrm{E}-01$ & $1.64 \mathrm{E}+11$ \\
\hline $1.454 \mathrm{E}-01$ & $1.07 \mathrm{E}+06$ & $6.263 \mathrm{E}-01$ & $1.24 \mathrm{E}+10$ \\
\hline $1.474 \mathrm{E}-01$ & $0.00 \mathrm{E}+00$ & $6.300 \mathrm{E}-01$ & $3.63 \mathrm{E}+07$ \\
\hline $1.727 \mathrm{E}-01$ & $1.77 \mathrm{E}+11$ & $6.360 \mathrm{E}-01$ & $9.99 \mathrm{E}+12$ \\
\hline $1.763 \mathrm{E}-01$ & $6.03 \mathrm{E}+12$ & $6.578 \mathrm{E}-01$ & $5.54 \mathrm{E}+12$ \\
\hline $1.765 \mathrm{E}-01$ & $0.00 \mathrm{E}+00$ & $6.617 \mathrm{E}-01$ & $1.63 \mathrm{E}+15$ \\
\hline $1.896 \mathrm{E}-01$ & $4.51 \mathrm{E}+05$ & $6.714 \mathrm{E}-01$ & $1.58 \mathrm{E}+12$ \\
\hline $2.041 \mathrm{E}-01$ & $2.92 \mathrm{E}+11$ & $6.776 \mathrm{E}-01$ & $6.06 \mathrm{E}+11$ \\
\hline $2.081 \mathrm{E}-01$ & $2.12 \mathrm{E}+11$ & $6.870 \mathrm{E}-01$ & $3.77 \mathrm{E}+11$ \\
\hline $2.279 \mathrm{E}-01$ & $1.15 \mathrm{E}+11$ & $6.959 \mathrm{E}-01$ & $2.96 \mathrm{E}+04$ \\
\hline $2.357 \mathrm{E}-01$ & $6.34 \mathrm{E}+08$ & 7.067E-01 & $9.62 \mathrm{E}+11$ \\
\hline $2.881 \mathrm{E}-01$ & $5.13 \mathrm{E}+06$ & $7.081 \mathrm{E}-01$ & $1.59 \mathrm{E}+10$ \\
\hline $2.950 \mathrm{E}-01$ & $3.93 \mathrm{E}+05$ & $7.242 \mathrm{E}-01$ & $9.66 \mathrm{E}+10$ \\
\hline $3.116 \mathrm{E}-01$ & $1.60 \mathrm{E}+06$ & $7.257 \mathrm{E}-01$ & $1.34 \mathrm{E}+07$ \\
\hline $3.210 \mathrm{E}-01$ & $3.63 \mathrm{E}+11$ & $7.296 \mathrm{E}-01$ & $6.88 \mathrm{E}+03$ \\
\hline $3.621 \mathrm{E}-01$ & $7.37 \mathrm{E}+04$ & 7.443E-01 & $2.77 \mathrm{E}+11$ \\
\hline $3.805 \mathrm{E}-01$ & $1.34 \mathrm{E}+12$ & $7.567 \mathrm{E}-01$ & $1.19 \mathrm{E}+11$ \\
\hline $4.081 \mathrm{E}-01$ & $1.59 \mathrm{E}+11$ & $7.639 \mathrm{E}-01$ & $1.30 \mathrm{E}+12$ \\
\hline $4.141 \mathrm{E}-01$ & $7.62 \mathrm{E}+06$ & $7.658 \mathrm{E}-01$ & $1.16 \mathrm{E}+07$ \\
\hline $4.279 \mathrm{E}-01$ & $2.62 \mathrm{E}+13$ & $7.958 \mathrm{E}-01$ & $1.38 \mathrm{E}+15$ \\
\hline $4.328 \mathrm{E}-01$ & $2.18 \mathrm{E}+06$ & $8.019 \mathrm{E}-01$ & $1.41 \mathrm{E}+14$ \\
\hline $4.436 \mathrm{E}-01$ & $2.65 \mathrm{E}+11$ & $8.180 \mathrm{E}-01$ & $4.30 \mathrm{E}+11$ \\
\hline $4.438 \mathrm{E}-01$ & $4.45 \mathrm{E}+05$ & $8.847 \mathrm{E}-01$ & $4.25 \mathrm{E}+12$ \\
\hline $4.468 \mathrm{E}-01$ & $2.19 \mathrm{E}+11$ & $9.153 \mathrm{E}-01$ & $7.01 \mathrm{E}+06$ \\
\hline $4.606 \mathrm{E}-01$ & $1.72 \mathrm{E}+05$ & $9.375 \mathrm{E}-01$ & $2.01 \mathrm{E}+12$ \\
\hline $4.634 \mathrm{E}-01$ & $9.28 \mathrm{E}+12$ & $9.973 \mathrm{E}-01$ & $7.66 \mathrm{E}+09$ \\
\hline $4.754 \mathrm{E}-01$ & $2.36 \mathrm{E}+13$ & $1.014 \mathrm{E}+00$ & $8.28 \mathrm{E}+06$ \\
\hline $4.971 \mathrm{E}-01$ & $1.19 \mathrm{E}+08$ & $1.039 \mathrm{E}+00$ & $1.62 \mathrm{E}+13$ \\
\hline 5.013E-01 & $2.75 \mathrm{E}+06$ & $1.168 \mathrm{E}+00$ & $2.92 \mathrm{E}+13$ \\
\hline $5.140 \mathrm{E}-01$ & $6.05 \mathrm{E}+11$ & $1.205 \mathrm{E}+00$ & $1.43 \mathrm{E}+08$ \\
\hline $5.336 \mathrm{E}-01$ & $1.15 \mathrm{E}+05$ & $1.334 \mathrm{E}+00$ & $8.25 \mathrm{E}+09$ \\
\hline $5.503 \mathrm{E}-01$ & $3.87 \mathrm{E}+07$ & $1.365 \mathrm{E}+00$ & $4.92 \mathrm{E}+13$ \\
\hline $5.532 \mathrm{E}-01$ & $1.64 \mathrm{E}+05$ & $1.384 \mathrm{E}+00$ & $1.42 \mathrm{E}+12$ \\
\hline $5.567 \mathrm{E}-01$ & $1.18 \mathrm{E}+03$ & $1.476 \mathrm{E}+00$ & $2.34 \mathrm{E}+11$ \\
\hline $5.570 \mathrm{E}-01$ & $1.14 \mathrm{E}+06$ & $1.505 \mathrm{E}+00$ & $7.63 \mathrm{E}+11$ \\
\hline 5.632E-01 & $1.36 \mathrm{E}+14$ & $1.562 \mathrm{E}+00$ & $6.01 \mathrm{E}+10$ \\
\hline
\end{tabular}


Table 2. Gamma Source Term after Five-Year Decay for Each Used Fuel Assembly

\begin{tabular}{|c|c|c|c|}
\hline Energy [MeV] & Photons/sec & Energy $[\mathrm{MeV}]$ & Photons/sec \\
\hline $1.113 \mathrm{E}-03$ & $1.06 \mathrm{E}+10$ & 6.067E-01 & $2.69 \mathrm{E}+12$ \\
\hline $3.357 \mathrm{E}-02$ & $5.64 \mathrm{E}+11$ & $6.103 \mathrm{E}-01$ & $1.91 \mathrm{E}+01$ \\
\hline $3.549 \mathrm{E}-02$ & $2.30 \mathrm{E}+12$ & $6.113 \mathrm{E}-01$ & $1.07 \mathrm{E}+01$ \\
\hline $4.098 \mathrm{E}-02$ & $7.34 \mathrm{E}+11$ & $6.204 \mathrm{E}-01$ & $2.17 \mathrm{E}+10$ \\
\hline $5.328 \mathrm{E}-02$ & $1.46 \mathrm{E}+00$ & $6.263 \mathrm{E}-01$ & $1.63 \mathrm{E}+09$ \\
\hline $7.570 \mathrm{E}-02$ & $2.17 \mathrm{E}+00$ & $6.300 \mathrm{E}-01$ & $1.73 \mathrm{E}+02$ \\
\hline $8.012 \mathrm{E}-02$ & $3.84 \mathrm{E}+12$ & $6.360 \mathrm{E}-01$ & $6.05 \mathrm{E}+12$ \\
\hline $9.848 \mathrm{E}-02$ & $4.81 \mathrm{E}+00$ & $6.578 \mathrm{E}-01$ & $7.31 \mathrm{E}+11$ \\
\hline $1.170 \mathrm{E}-01$ & $1.50 \mathrm{E}+11$ & $6.617 \mathrm{E}-01$ & $1.56 \mathrm{E}+15$ \\
\hline $1.335 \mathrm{E}-01$ & $3.13 \mathrm{E}+13$ & $6.714 \mathrm{E}-01$ & $9.58 \mathrm{E}+11$ \\
\hline $1.727 \mathrm{E}-01$ & $1.07 \mathrm{E}+11$ & $6.776 \mathrm{E}-01$ & $7.99 \mathrm{E}+10$ \\
\hline $1.763 \mathrm{E}-01$ & $3.65 \mathrm{E}+12$ & $6.870 \mathrm{E}-01$ & $4.97 \mathrm{E}+10$ \\
\hline $2.041 \mathrm{E}-01$ & $1.77 \mathrm{E}+11$ & $7.067 \mathrm{E}-01$ & $1.27 \mathrm{E}+11$ \\
\hline $2.081 \mathrm{E}-01$ & $1.28 \mathrm{E}+11$ & $7.081 \mathrm{E}-01$ & $2.10 \mathrm{E}+09$ \\
\hline $2.279 \mathrm{E}-01$ & $6.96 \mathrm{E}+10$ & $7.242 \mathrm{E}-01$ & $3.57 \mathrm{E}+07$ \\
\hline $2.357 \mathrm{E}-01$ & $2.35 \mathrm{E}+05$ & 7.257E-01 & $6.40 \mathrm{E}+01$ \\
\hline $2.881 \mathrm{E}-01$ & $2.45 \mathrm{E}+01$ & 7.443E-01 & $3.65 \mathrm{E}+10$ \\
\hline $3.210 \mathrm{E}-01$ & $2.19 \mathrm{E}+11$ & $7.567 \mathrm{E}-01$ & $4.41 \mathrm{E}+07$ \\
\hline $3.805 \mathrm{E}-01$ & $8.13 \mathrm{E}+11$ & $7.639 \mathrm{E}-01$ & $1.72 \mathrm{E}+11$ \\
\hline $4.081 \mathrm{E}-01$ & $9.63 \mathrm{E}+10$ & 7.658E-01 & $6.06 \mathrm{E}+00$ \\
\hline $4.141 \mathrm{E}-01$ & $3.64 \mathrm{E}+01$ & $7.958 \mathrm{E}-01$ & $7.06 \mathrm{E}+14$ \\
\hline 4.279E-01 & $1.58 \mathrm{E}+13$ & $8.019 \mathrm{E}-01$ & $7.22 \mathrm{E}+13$ \\
\hline $4.328 \mathrm{E}-01$ & $1.04 \mathrm{E}+01$ & $8.180 \mathrm{E}-01$ & $5.67 \mathrm{E}+10$ \\
\hline 4.436E-01 & $1.61 \mathrm{E}+11$ & $8.847 \mathrm{E}-01$ & $5.61 \mathrm{E}+11$ \\
\hline $4.468 \mathrm{E}-01$ & $2.89 \mathrm{E}+10$ & $9.153 \mathrm{E}-01$ & $3.35 \mathrm{E}+01$ \\
\hline 4.634E-01 & $5.62 \mathrm{E}+12$ & $9.375 \mathrm{E}-01$ & $2.65 \mathrm{E}+11$ \\
\hline 4.754E-01 & $1.21 \mathrm{E}+13$ & $9.973 \mathrm{E}-01$ & $1.01 \mathrm{E}+09$ \\
\hline $4.971 \mathrm{E}-01$ & $3.02 \mathrm{E}+02$ & $1.014 \mathrm{E}+00$ & $3.95 \mathrm{E}+01$ \\
\hline $5.013 \mathrm{E}-01$ & $1.31 \mathrm{E}+01$ & $1.039 \mathrm{E}+00$ & $8.27 \mathrm{E}+12$ \\
\hline $5.140 \mathrm{E}-01$ & $5.32 \mathrm{E}+11$ & $1.168 \mathrm{E}+00$ & $1.49 \mathrm{E}+13$ \\
\hline 5.503E-01 & $1.85 \mathrm{E}+02$ & $1.205 \mathrm{E}+00$ & $2.52 \mathrm{E}+04$ \\
\hline $5.570 \mathrm{E}-01$ & $2.89 \mathrm{E}+00$ & $1.334 \mathrm{E}+00$ & $1.09 \mathrm{E}+09$ \\
\hline $5.632 \mathrm{E}-01$ & $6.93 \mathrm{E}+13$ & $1.365 \mathrm{E}+00$ & $2.51 \mathrm{E}+13$ \\
\hline $5.693 \mathrm{E}-01$ & $1.28 \mathrm{E}+14$ & $1.384 \mathrm{E}+00$ & $1.88 \mathrm{E}+11$ \\
\hline $5.997 \mathrm{E}-01$ & $2.44 \mathrm{E}+01$ & $1.476 \mathrm{E}+00$ & $3.09 \mathrm{E}+10$ \\
\hline $6.006 \mathrm{E}-01$ & $9.58 \mathrm{E}+12$ & $1.505 \mathrm{E}+00$ & $1.01 \mathrm{E}+11$ \\
\hline $6.047 \mathrm{E}-01$ & $8.07 \mathrm{E}+14$ & $1.562 \mathrm{E}+00$ & $7.93 \mathrm{E}+09$ \\
\hline
\end{tabular}


Table 3. Activation Product Co-60 Source Term after Three-Year Decay for Each Set of Used Fuel Assembly Components

\begin{tabular}{|c|c|}
\hline Cobalt-60 source & Activity [curies] \\
\hline lower end fitting & 227.04 \\
\hline grid spacers & 588 \\
\hline plenum springs & 17.32 \\
\hline expansion springs & 9.94 \\
\hline top end fitting & 111.36 \\
\hline
\end{tabular}

Table 4. Neutron Source Term for Each Used Fuel Assembly

\begin{tabular}{|c|c|}
\hline Neutron Energy Range [MeV] & Neutrons/sec \\
\hline $1.00 \mathrm{E}-01$ to $4.00 \mathrm{E}-01$ & $1.80 \mathrm{E}+07$ \\
\hline $4.00 \mathrm{E}-01$ to $9.00 \mathrm{E}-01$ & $9.21 \mathrm{E}+07$ \\
\hline $9.00 \mathrm{E}-01$ to $1.40 \mathrm{E}+00$ & $8.43 \mathrm{E}+07$ \\
\hline $1.40 \mathrm{E}+00$ to $1.85 \mathrm{E}+00$ & $6.21 \mathrm{E}+07$ \\
\hline $1.85 \mathrm{E}+00$ to $3.00 \mathrm{E}+00$ & $1.09 \mathrm{E}+08$ \\
\hline $3.00 \mathrm{E}+00$ to $6.43 \mathrm{E}+00$ & $9.96 \mathrm{E}+07$ \\
\hline $6.43 \mathrm{E}+00$ to $2.00 \mathrm{E}+01$ & $8.84 \mathrm{E}+06$ \\
\hline
\end{tabular}

\subsection{Geometry}

The dimensions of the sample dry-storage cask utilized for analysis were based upon existing designs. The HI-STORM 100 system is a sample design in use by the nuclear industry today that was used in this work ${ }^{15}$. The nominal dimensions of the 
shorter version of this system, HI-STORM 100S, Version B(218), were used to generate the MCNP model. When possible features would be explicitly modeled, however, some approximations were necessary both to limit runtime and due to the privacy of the data on this product. The basic schematic can be seen in Figure 1, which also indicates the placement of the steel MPC within the system. The over-pack is $1.67 \mathrm{~m}$ in radius and 5.6 $\mathrm{m}$ high, with a $0.93 \mathrm{~m}$ radius cavity for the MPC.

Simplifications primarily focused on the lid, which contains a complex geometry, but is less significant for uncertainty calculations focused on concrete density and composition effects due to the large amount of steel plates that serve as the primary shielding in this regions. The presence of the vents and their removable steel shielding meant that results would vary widely over the area of the lid, which made this region of the systems less suitable for this analysis. Sample simplifications include ignoring minor penetrations, extrusions, filets, and chamfers. Features that were simplified were replaced by void as a conservative assumption to minimize their effect on the shielding. A few of the more significant simplifications include simplifying bolt geometries and ignoring the lift plug penetration.

In addition to the HI-STORM over-pack itself, it was necessary to model the MPC-32, in order to accurately determine the effect of radiation shielding design. The MPC is designed to hold a varying number of used fuel assemblies for various boiling BWRs and PWRs. The different MPC designs are specified by the number of assemblies that can be safely stored within. The MPC-32 is designed to hold 32 standard PWR assemblies. It is this canister type that is modeled and for this study. 


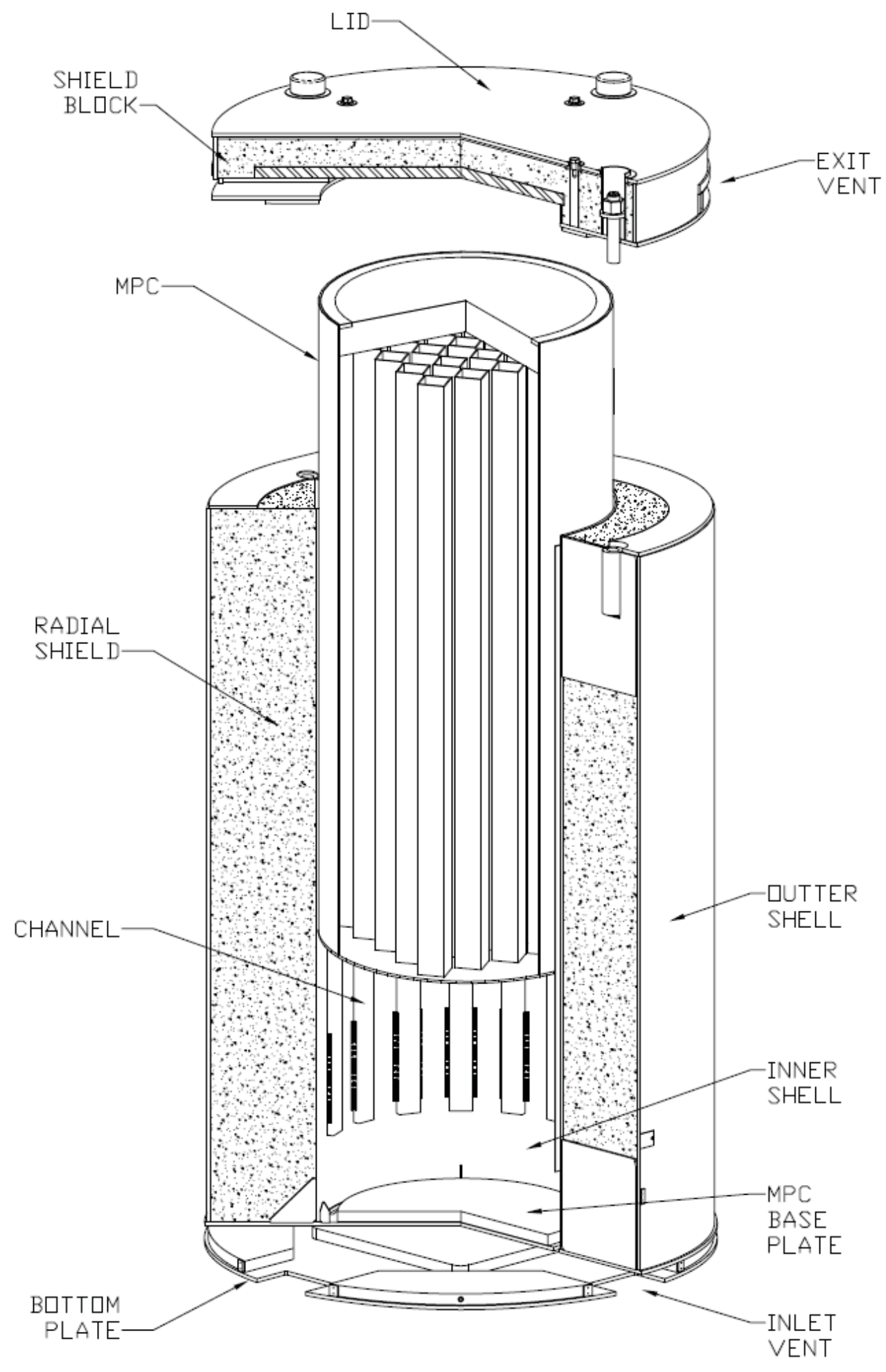

Figure 1. Schematic of HI-STORM 100S Cask ${ }^{15}$. 
The MPC-32 shell was modeled as a $1.27 \mathrm{~cm}$ thick cylinder of type 304 stainless steel with a $6.35 \mathrm{~cm}$ thick base and $24.14 \mathrm{~cm}$ thick lid also of type 304 stainless steel $^{16}$. The MPC is $4.84 \mathrm{~m}$ high and has a radius of $0.86 \mathrm{~m}$. The base plate and lid were modeled as simple disks, with areas of reduced thicknesses at vents and drains. Minor structural details such as the port openings and lid penetrations were simplified but thicknesses of steel were maintained to increase accuracy in shielding calculations. Minimum values from the thicknesses ranges mentioned were used.

The contents of the MPC included in the model were 32 UNF assemblies, a fuel basket structure for each assembly location, basket supports, Boral shield to prevent criticality accidents (even when canister is filled with water), upper and lower fuel spacers and the aforementioned drain tube. The heights of the upper and lower fuel spacers were adjusted to place the fuel assembly in the middle of the canister (along the cask axial direction) and to fill the space between the bottom/top of the fuel assembly and the base/lid of the canister. Spacer geometry was simplified and spacers were modeled relative thin as a conservative estimate.

The fuel assembly was modeled as a standard Westinghouse 17 X 17 PWR assembly as used by CPNPP to maintain consistency with the source data provided. The reference dimensions and materials for these basic assembly layouts are available from a variety of public sources at the level of accuracy necessary for this analysis, which included basic fuel and clad dimensions, as well as the location of control rod guides and instrumentation tubes, but not structural details such as the dimensions of grid spacers ${ }^{17}$. Figure 2 shows the details of a fuel assembly generated using the VISED. 


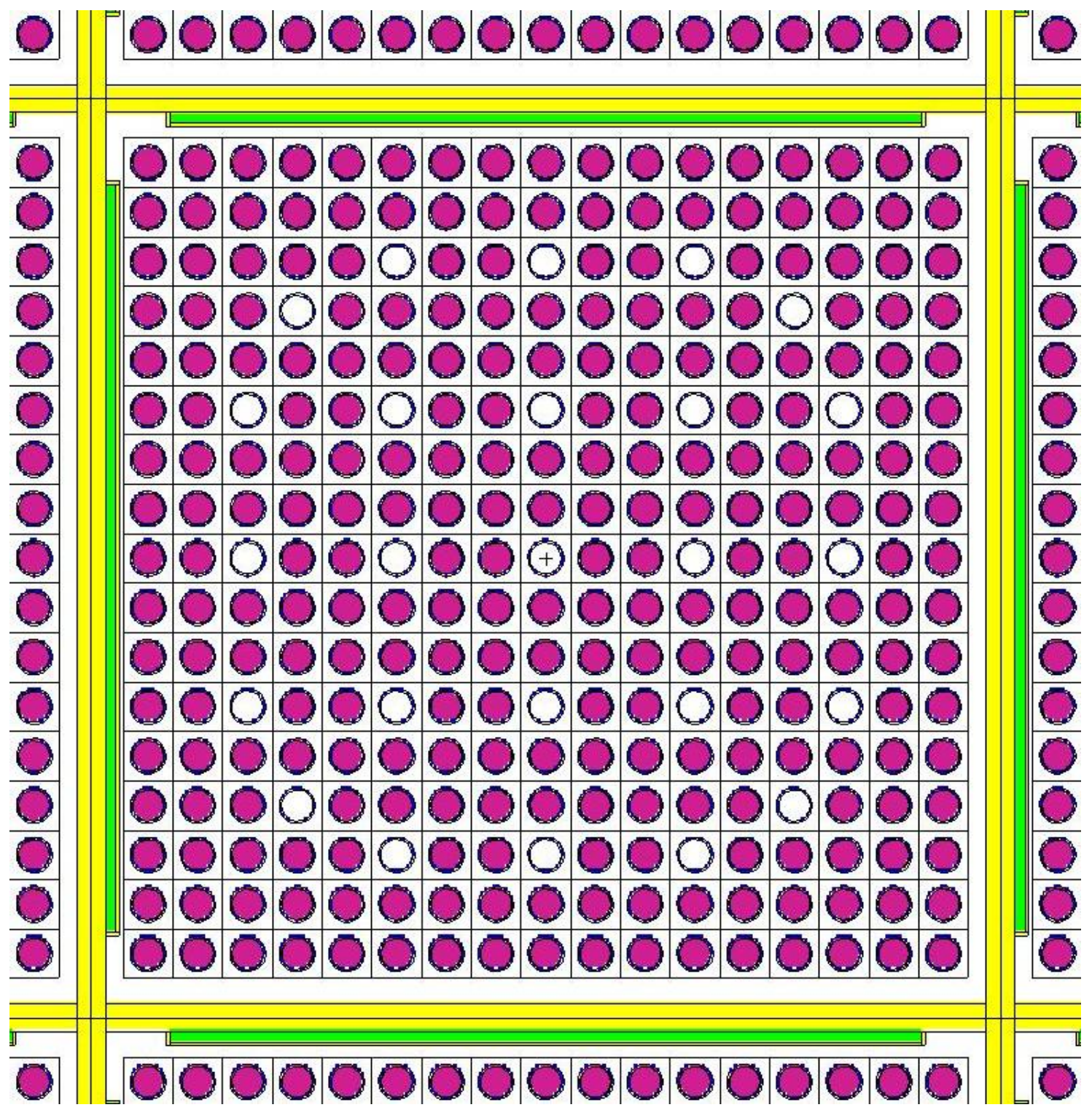

\begin{tabular}{|l|l|}
\hline Material & Color \\
\hline $\mathrm{UO}_{2}$ & \\
\hline Zircaloy-4 & \\
\hline $\mathrm{S} / \mathrm{S}$ (MPC/Fuel) & \\
\hline Boral & \\
\hline S/S (HI-STORM) & \\
\hline Concrete & All other colors \\
\hline Modeled as C/S & \\
\hline
\end{tabular}

Figure 2. VISED rendering of a Westinghouse $17 \times 17$ fuel assembly in the Boral sheath. 
The MCNP model was generated and rendered using VISED after analyzing this geometric information. Figure 3 shows an overall view of the HI-STORM 100 system when filled with fuel. Plan views 1 and 2 in this image show the structure of the overpack base plate, including that allows air circulation and cooling. Plan view 3 shows the steel platform that supports MPC itself, surrounded by shielding, while plan view 4 shows the base of the MPC itself. Plan view 5 displays the fuel spacers, which are used to hold the fuel at the axial center of the shielding. Figure 4 displays a more detailed rendering of the central fuel plane, which corresponds to plan view 6 , the primary area of interest for this analysis, due to the radial shielding in this area depending primarily upon the concrete properties. The HI-STORM over-pack in this region consists of two radial $2.54 \mathrm{~cm}$ thick stainless steel sheets and $69.85 \mathrm{~cm}$ of concrete. Plan view 7 shows the lid of the MPC, surrounded by the over-pack shielding. Plan view 8 illustrates the interface between the over-pack lid and body, while views 9 and 10 show the vent structure and shielding. Finally, plan views 11 and 12 illustrate the lid shielding and top plate. These images overall demonstrate that the model contains a detailed representation of all the structures of importance in the HI-STROM 100S dry-cask storage system. 
Elevation View of MPC-32 and HI-STORM 100S VERSION B OVERPACK

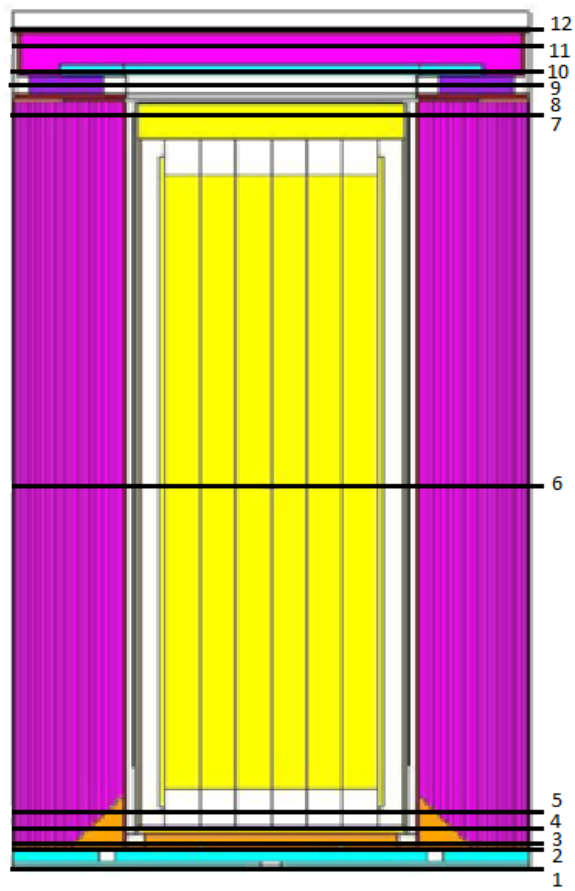

Plan view at various elevations
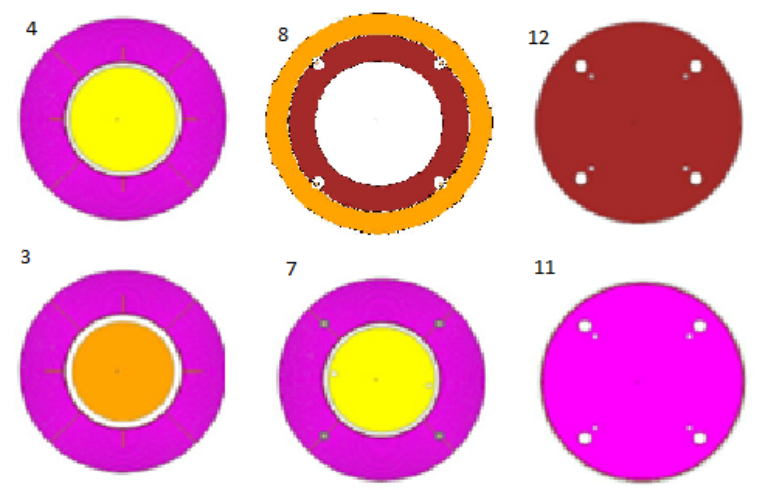

11
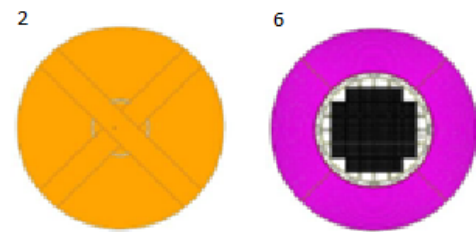

10
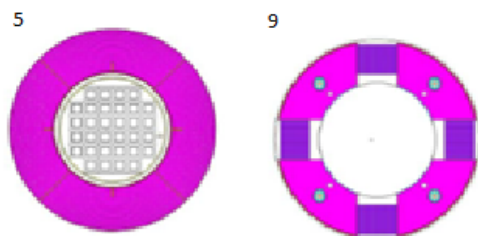

\begin{tabular}{|l|l|}
\hline Material & Color \\
\hline $\mathrm{UO}_{2}$ & \\
\hline Zircaloy-4 & \\
\hline $\mathrm{S} / \mathrm{S}$ (MPC/Fuel) & \\
\hline Boral & \\
\hline $\mathrm{S} / \mathrm{S}$ (HI-STORM) & \\
\hline Concrete & All other colors \\
\hline Modeled as C/S & \\
\hline
\end{tabular}

Figure 3. VISED rendering of MPC-32 contained in HI-STORM 100S Version B (218). 


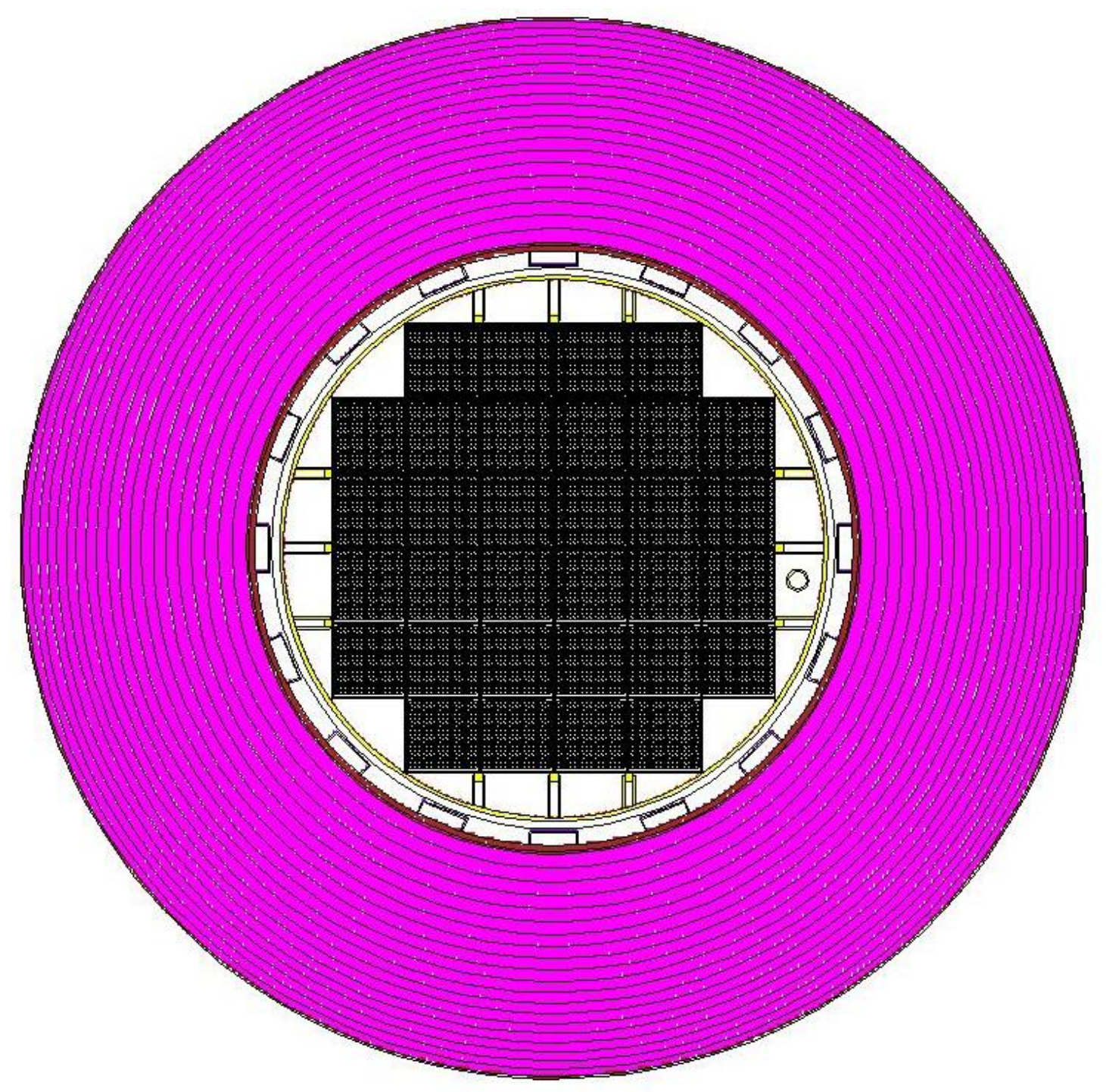

\begin{tabular}{|l|l|}
\hline Material & Color \\
\hline $\mathrm{UO}_{2}$ & \\
\hline Zircaloy-4 & \\
\hline $\mathrm{S} / \mathrm{S}$ (MPC/Fuel) & \\
\hline Boral & \\
\hline $\mathrm{S} / \mathrm{S}$ (HI-STORM) & \\
\hline Concrete & \\
\hline Modeled as C/S & All other colors \\
\hline
\end{tabular}

Figure 4. VISED rendering of the central plane of the fueled region. 
Figure 5 shows the relationship between the source term and the geometry, since the brown particles, representing the particles generated by the source term, were confined to the individual assemblies, rather than spread throughout the MPC region. The figure shows a random sampling of particles generated within $100 \mathrm{~cm}$ above or below the plane of study, the center of the fuel assembly. Each assembly source was individually defined as part of the $\mathrm{x}$ and $\mathrm{y}$ distribution in the MCNP input to obtain this result, while universal $\mathrm{z}$ limits were assigned, since the cask would typically be on a flattened pad. The distribution for the gamma rays from fission products, the neutrons from actinides, and the neutrons used to determine the gamma rays from neutron capture were all integrated into the model. The ${ }^{60} \mathrm{Co}$ source also conforms to this pattern, though the particles are only generated in limited $\mathrm{z}$ regions that are waited to reflect the relative number of activated structural nuclei at each region of the assembly. This process was also used to confirm the basic energy distribution of the source by assigning different color markers to different energy levels during testing. 


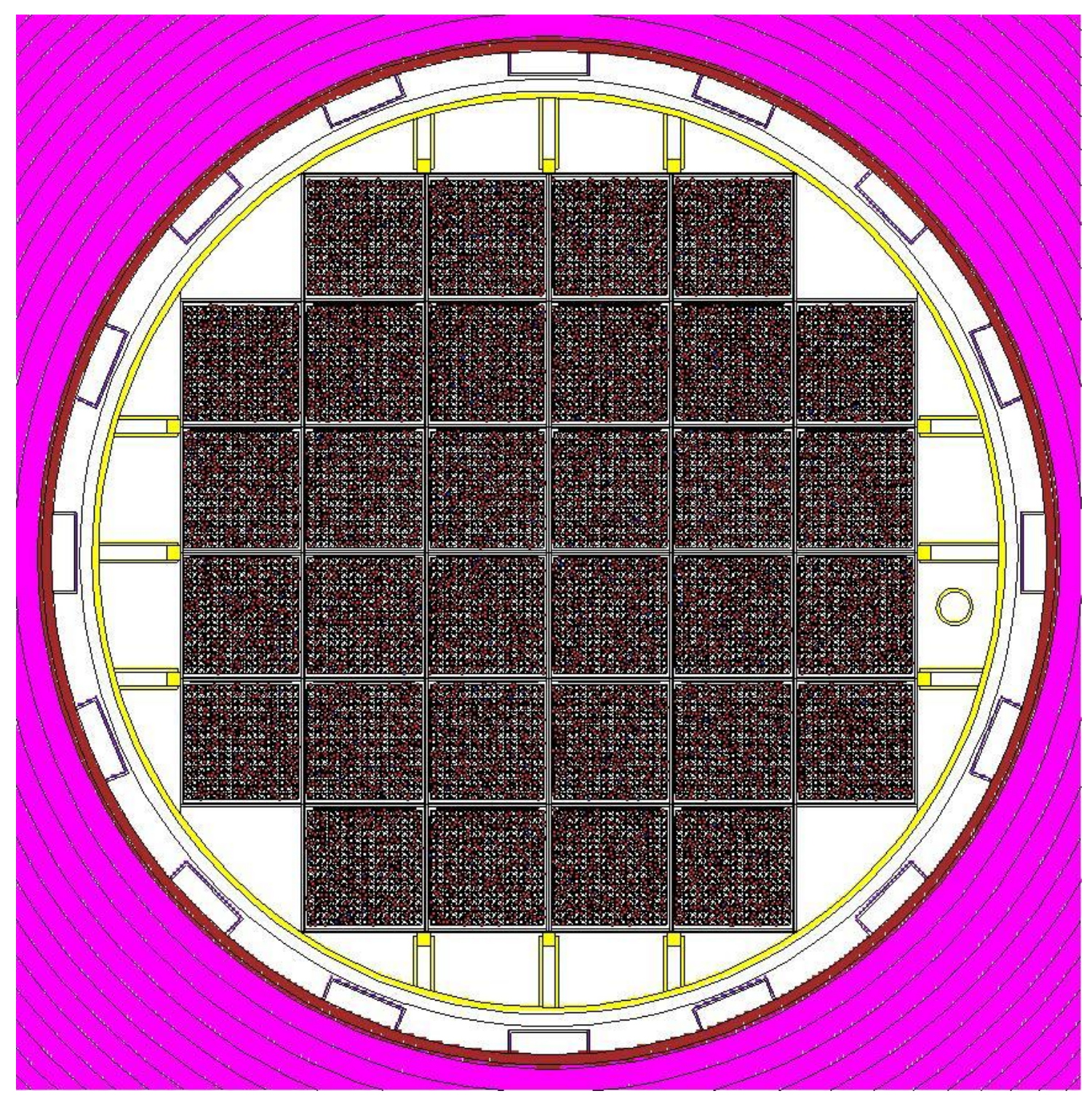

\begin{tabular}{|l|l|}
\hline Material & Color \\
\hline $\mathrm{UO}_{2}$ & \\
\hline Zircaloy-4 & \\
\hline $\mathrm{S} / \mathrm{S}$ (MPC/Fuel) & \\
\hline Boral & \\
\hline $\mathrm{S} / \mathrm{S}$ (HI-STORM) & \\
\hline Concrete & All other colors \\
\hline Modeled as C/S
\end{tabular}

Figure 5. Source particle distribution in the fueled regions. 


\subsection{Fuel and Structural Materials}

The material specifications used in the model are of upmost importance as the associated radiation shielding calculations are heavily dependent on individual material properties. This section addresses the materials that are held constant throughout the studies: the materials of the fuel assembly, the materials of the MPC, and the structural materials of the over-pack itself. While material information was located for all materials in the MPC, detailed material data was unavailable for some materials in the over-pack itself. To account for this, all materials in the over-pack itself except for concrete and stainless steel are currently modeled as carbon steel, due to a lack of detailed composition and density data. Since most parts are small, with minimal impact of the shielding, distant from the fuel, and made of ferrous materials (ASME code SA), this is a reasonable approximation. A similar estimation was used for the PVC caps on the lid, due to their distance from the source and low impact on this study.

The fuel in the MPC was modeled as standard $\mathrm{UO}_{2}$ fuel with $4 \mathrm{wt} \%{ }^{235} \mathrm{U}$ enrichment. Fuel was treated as fresh fuel due to unknown fission product distributions. The gap in the fuel pin is void and the fuel clad is zircaloy-4. The assembly baskets, basket supports, drain tube, drain and vent port blocks, MPC containment, MPC lid and base are all modeled as type-304 stainless steel. The Boral shielding is standard aluminum and boron carbide, containing $0.21 \%$ B-10. The Boral sheaths are also type304 stainless steel.

The densities of the compositions used in the HI-STORM 100S Version B (218) cask and the MPC-32 can be found in Table 5. Air was modeled as void as a 
conservative approximation and to avoid potential complications of varied air densities.

It is assumed that density or composition changes due to temperature change were negligible.

Table 5. Compositions Used in the HI-STORM Cask and MPC-32

\begin{tabular}{|c|c|c|c|}
\hline Material & Density $\left[\mathrm{g} / \mathrm{cm}^{3}\right]$ & Elements & Percent Mass \\
\hline \multirow[t]{3}{*}{ Fuel (UO2) } & \multirow[t]{3}{*}{10.46} & $U-235$ & 3.49 \\
\hline & & $\mathrm{U}-238$ & 84.93 \\
\hline & & $0-16$ & 11.58 \\
\hline \multirow{5}{*}{$\begin{array}{l}\text { Fuel Cladding } \\
\text { (Zircaloy-4) }\end{array}$} & \multirow[t]{5}{*}{6.55} & $\mathrm{Zr}$ & 98.23 \\
\hline & & Sn & 1.45 \\
\hline & & $\mathrm{Fe}$ & 0.21 \\
\hline & & $\mathrm{Cr}$ & 0.1 \\
\hline & & $\mathrm{Hf}$ & 0.01 \\
\hline \multirow[t]{4}{*}{ Boral } & \multirow[t]{4}{*}{1.7} & $\mathrm{Al}$ & 68.61 \\
\hline & & C & 6.82 \\
\hline & & B-10 & 4.4226 \\
\hline & & B-11 & 20.1474 \\
\hline \multirow[t]{4}{*}{ SS304 } & \multirow[t]{4}{*}{7.92} & $\mathrm{Cr}$ & 19 \\
\hline & & $\mathrm{Mn}$ & 2 \\
\hline & & $\mathrm{Fe}$ & 69.5 \\
\hline & & $\mathrm{Ni}$ & 9.5 \\
\hline \multirow[t]{2}{*}{ Carbon Steel } & \multirow[t]{2}{*}{7.82} & C & 0.5 \\
\hline & & $\mathrm{Fe}$ & 99.5 \\
\hline
\end{tabular}




\section{CONCRETE COMPOSITIONS}

The primary material of interest in this study was the concrete itself. A variety of commercial concrete variants have been summarized by the Pacific Northwest National Laboratory. The varieties of concrete used for analysis include the Standard Concrete specified by the Los Alamos National Laboratory, NBS Concrete Specifications 03 and 04, and the dry version of Hanford Concrete.

Standard Concrete is representative of the typical concrete used in construction. It is not designed for special shielding properties, however, its high density when compared to most materials, as well as the hydrogen content of the concrete, make it an effective shield, especially if the radiation must first pass through a material with a high atomic number, such as the systems stainless steel frame. The reference Los Alamos National Laboratory specification for this material was utilized.

INBS concrete is a composition that corresponds to a specification published by the Royal Institute of British Architects that serves as the national standard specification system for the United Kingdom, and is used internationally ${ }^{18}$. The specification can be used as a reasonable approximation of the concrete composition of various vendors that utilize the standard. NBS 03 and NBS 04 are two different specifications that are commonly referenced.

Hanford concrete is an industrial brand of concrete produced by Hanford Ready Mix, Inc. ${ }^{19}$. It is a sample ordinary concrete brand manufactured in the United States. 
The dry version of the concrete composition is used, assuming that residual decay heat from the assembly will make this more appropriate than the wet version.

The nominal density and composition details of each of these materials can be seen in Table 6.

While potentially higher density, specialized shielding concretes such as barite concrete, iron-portland concrete, or magnetite concrete could be utilized to increase the shielding, these materials are more expensive and weigh significantly more, complicating transport of the cask on site and adding additional strain to the structural components of the dry storage cask. While a user could use a mixture including some of these heavier aggregates, such a mixture does not have a standardized composition and thus is beyond the scope of this study. 
Table 6. Concrete Composition Details.

\begin{tabular}{|c|c|c|c|}
\hline Material & Density $\left[\mathrm{g} / \mathrm{cm}^{3}\right]$ & Elements & Percent Mass \\
\hline \multirow{7}{*}{ Standard Concrete } & \multirow{7}{*}{2.25} & $\mathrm{H}-1$ & $0.453 \%$ \\
\hline & & $0-16$ & $51.260 \%$ \\
\hline & & $\mathrm{Na}-23$ & $1.527 \%$ \\
\hline & & Al-27 & $3.555 \%$ \\
\hline & & $\mathrm{Si}$ & $36.036 \%$ \\
\hline & & $\mathrm{Ca}$ & $5.791 \%$ \\
\hline & & $\mathrm{Fe}$ & $1.378 \%$ \\
\hline \multirow{10}{*}{ NBS 03 Concrete } & \multirow{10}{*}{2.35} & $\mathrm{H}-1$ & $0.849 \%$ \\
\hline & & $\mathrm{C}$ & $5.006 \%$ \\
\hline & & $0-16$ & $47.348 \%$ \\
\hline & & $\mathrm{Mg}$ & $2.418 \%$ \\
\hline & & $\mathrm{Al}-27$ & $3.606 \%$ \\
\hline & & $\mathrm{Si}$ & $14.510 \%$ \\
\hline & & $\mathrm{S}$ & $0.297 \%$ \\
\hline & & $\mathrm{K}$ & $0.170 \%$ \\
\hline & & $\mathrm{Ca}$ & $24.692 \%$ \\
\hline & & $\mathrm{Fe}$ & $1.103 \%$ \\
\hline \multirow{10}{*}{ NBS 04 Concrete } & \multirow{10}{*}{2.35} & $\mathrm{H}-1$ & $0.556 \%$ \\
\hline & & $0-16$ & $49.808 \%$ \\
\hline & & $\mathrm{Na}-23$ & $1.710 \%$ \\
\hline & & $\mathrm{Mg}$ & $0.257 \%$ \\
\hline & & $\mathrm{Al}-27$ & $4.575 \%$ \\
\hline & & $\mathrm{Si}$ & $31.509 \%$ \\
\hline & & $\mathrm{S}$ & $0.128 \%$ \\
\hline & & $\mathrm{K}$ & $1.924 \%$ \\
\hline & & $\mathrm{Ca}$ & $8.294 \%$ \\
\hline & & $\mathrm{Fe}$ & $1.240 \%$ \\
\hline \multirow{9}{*}{ Hanford Dry Concrete } & \multirow{9}{*}{2.18} & $\mathrm{H}-1$ & $0.400 \%$ \\
\hline & & $0-16$ & $48.210 \%$ \\
\hline & & $\mathrm{Na}-23$ & $0.217 \%$ \\
\hline & & $\mathrm{Mg}$ & $1.409 \%$ \\
\hline & & $\mathrm{Al}-27$ & $6.939 \%$ \\
\hline & & $\mathrm{Si}$ & $27.755 \%$ \\
\hline & & $\mathrm{K}$ & $1.301 \%$ \\
\hline & & $\mathrm{Ca}$ & $8.023 \%$ \\
\hline & & $\mathrm{Fe}$ & $5.746 \%$ \\
\hline
\end{tabular}




\section{MODELING PARAMETERS}

In shielding computations using the Monte Carlo method like the one used in MCNP code, it is necessary that the importance of a particle penetrating the shield be increased as it travels through more and more mean free paths. By increasing the importance, the particle is split into multiple copies of itself, but the weight of each copy is decreased. This accounts for the effects of attenuation as the particles pass through a shielding material. Only with this altered importance are the statistics of the final scored flux or dose rate statistically meaningful. To account for this, the model included radial splitting of the shielding region cells. Splitting is based upon the number of mean free paths predicted at a given average energy.

The MCNP code was executed using $10^{9}$ particles and run until the desired statistical convergence was achieved to get the average result per starting source particle per second, which was multiplied by the total source strength of neutron and gamma rays that started from the 32 UNF assemblies stored in the MPC-32 fuel baskets. Separate tallies were used for each source type. Ring tallies were performed at a distance of $1 \mathrm{~m}$ from the dry cask. The axial locations of these tallies are shown in Figure 6.

Multiple cases were run for each composition. Each concrete composition was run at nominal density using both the three-years-cooled and five-years-cooled source terms to compare the effectiveness of each material and to determine whether the altered energy spectrum caused significant changes in shielding effectiveness. Then, a set of cases was run leaving the source fixed at the three-years-cooled state while altering the 
concrete from nominal density to determine how significant a deviation from this value was, since many concrete compositions have a range of specified densities. This is particularly important since the quality control of the concrete must be performed on-site when filling the casks, which can lead to deviations from the specified values.

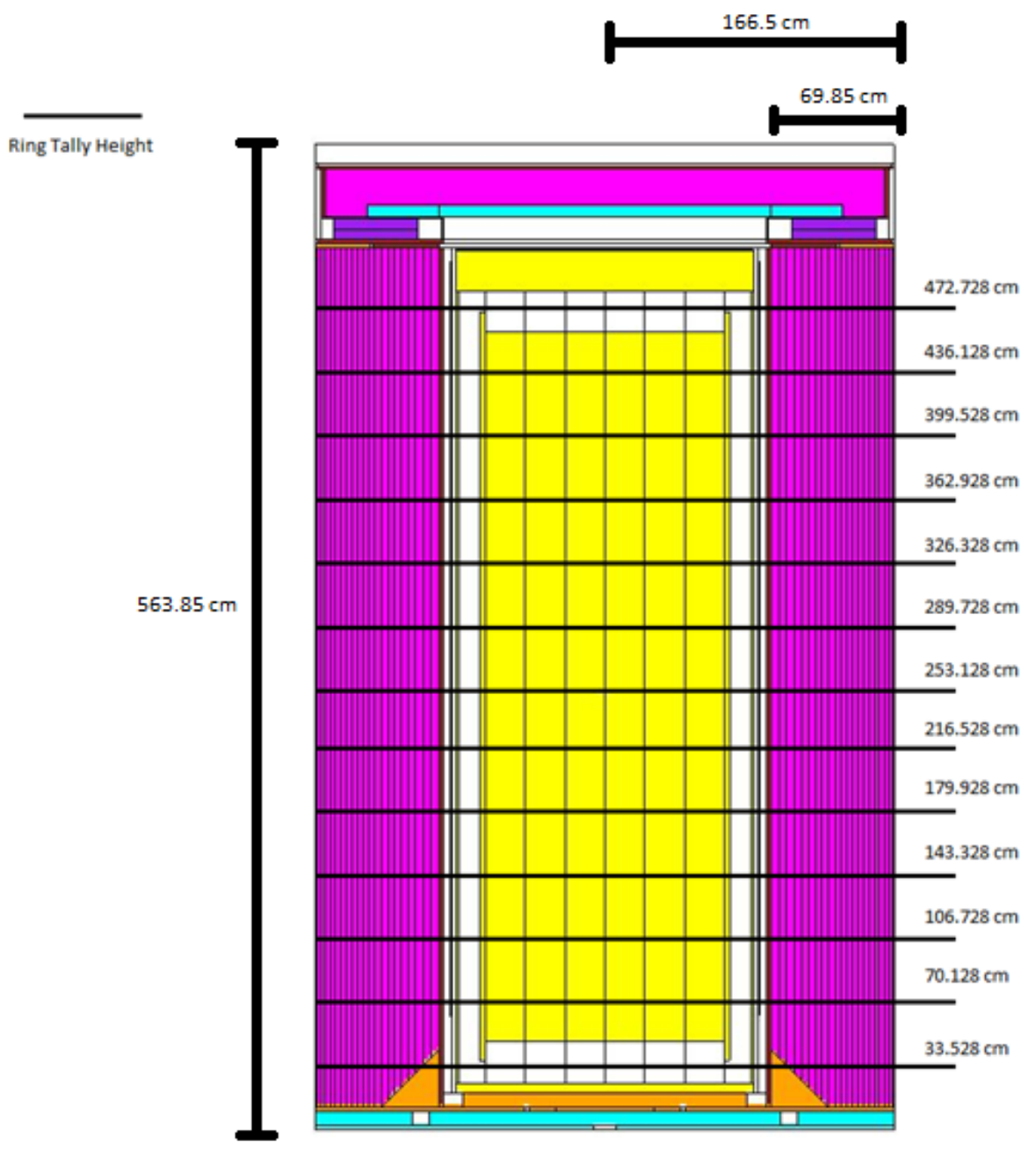

Figure 6. Axial positions of single cask ring tallies. 


\section{RESULTS AND EVALUATION}

\subsection{Common Result Characteristics}

In accordance with the project objectives, analysis was performed on a single cask model, determining the equivalent radiation dose rate at various heights while utilizing different concrete compositions and densities. Separate cases were run for radiation dose due to gamma rays from the $32 \mathrm{UNF}$ assemblies inside the dry cask, gamma rays from the activated portions of the fuel assemblies, neutrons from the fuel source, and gamma rays produced by neutron capture reactions. All results were determined at one meter from the cask periphery. All reported values had standard deviations of less than $\pm 10 \%$ due to statistical uncertainty introduced by the MCNP calculation methodology. Typical uncertainty values were far lower than $\pm 10 \%$, but outliers approached $\pm 10 \%$. It should be noted, however, that there will be additional contributions to the uncertainty due to modeling assumptions, engineering tolerances, and cross-section uncertainty in the nuclear data files.

\subsection{Results at Nominal Density and Composition}

The results for each of the concrete compositions discussed above were determined, and total dose rates calculated. Table 7 contains computed dose rate information for the standard composition, Table 8 summarizes the information for NBS 03 concrete, Table 9 contains the information for NBS 04 concrete, and Table 10 has the information for the Hanford mixture. These tables generally indicate that the primary dose rate of interest is the dose rate from gamma fission products, which typically 
contributes more than $70 \%$ of the total equivalent dose rate. Contributions from the activation products were typically relatively small, and were most significant near the bottom and top of the cask, where these sources were concentrated and where the effects of the uniform photon and neutron sources for the irradiated fuel were reduced. Comparison of the table reveals a strong dependence on the concrete density, as expected in shielding problems, with more significant differences between the total equivalent dose rate of the Hanford, Standard, and NBS cases than between the NBS cases themselves, which have the same density. Detailed analysis of the effect of varying density can be seen from other results. The NBS 03 concrete composition had the lowest total dose rate. 
Table 7. Equivalent Dose Rate of a Single Cask Shielded by Standard Concrete

\begin{tabular}{|r|c|r|r|r|r|}
\hline $\begin{array}{c}\text { Elevation } \\
\text { [cm] }\end{array}$ & $\begin{array}{c}\text { fission } \\
\text { product } \\
\text { gamma } \\
\text { dose at 1 } \\
\text { meter } \\
\text { [mrem/h] }\end{array}$ & $\begin{array}{c}\text { Co-60 } \\
\text { gamma } \\
\text { dose at 1 } \\
\text { meter } \\
\text { [mrem/h] }\end{array}$ & $\begin{array}{c}\text { neutron } \\
\text { dose at 1 } \\
\text { meter } \\
\text { [mrem/h] }\end{array}$ & $\begin{array}{c}\text { neutron } \\
\text { capture } \\
\text { gamma } \\
\text { dose at 1 } \\
\text { meter } \\
\text { [mrem/h] }\end{array}$ & $\begin{array}{c}\text { total dose at } \\
\mathbf{1} \text { meter } \\
\text { [mrem/hr] }\end{array}$ \\
\hline 33.53 & 16.706 & 0.772 & 3.633 & 2.355 & 23.466 \\
\hline 70.13 & 25.725 & 0.864 & 4.117 & 3.084 & 33.789 \\
\hline 106.73 & 34.632 & 0.755 & 4.803 & 3.760 & 43.949 \\
\hline 143.33 & 40.852 & 0.571 & 5.372 & 4.325 & 51.121 \\
\hline 179.93 & 44.536 & 0.443 & 5.731 & 4.721 & 55.430 \\
\hline 216.53 & 47.278 & 0.387 & 5.946 & 4.944 & 58.556 \\
\hline 253.13 & 47.987 & 0.368 & 5.940 & 5.012 & 59.307 \\
\hline 289.73 & 48.712 & 0.374 & 5.783 & 4.927 & 59.795 \\
\hline 326.33 & 44.988 & 0.395 & 5.508 & 4.693 & 55.585 \\
\hline 362.93 & 40.577 & 0.451 & 5.089 & 4.273 & 50.390 \\
\hline 399.53 & 34.488 & 0.541 & 4.425 & 3.701 & 43.155 \\
\hline 436.13 & 25.300 & 0.605 & 3.546 & 2.996 & 32.446 \\
\hline 472.73 & 15.773 & 0.583 & 2.917 & 2.268 & 21.540 \\
\hline & & & & & \\
\hline
\end{tabular}


Table 8. Equivalent Dose Rate of a Single Cask Shielded by NBS 03 Concrete

\begin{tabular}{|r|r|r|r|r|r|}
\hline $\begin{array}{c}\text { Elevation } \\
\text { [cm] }\end{array}$ & $\begin{array}{c}\text { fission } \\
\text { product } \\
\text { gamma } \\
\text { dose at 1 } \\
\text { meter } \\
\text { [mrem/h] }\end{array}$ & $\begin{array}{c}\text { Co-60 } \\
\text { gamma } \\
\text { dose at 1 } \\
\text { meter } \\
\text { [mrem/h] }\end{array}$ & $\begin{array}{c}\text { neutron } \\
\text { dose at 1 } \\
\text { meter } \\
\text { [mrem/h] }\end{array}$ & $\begin{array}{c}\text { neutron } \\
\text { capture } \\
\text { gamma } \\
\text { dose at 1 } \\
\text { meter } \\
\text { [mrem/h] }\end{array}$ & $\begin{array}{c}\text { total dose at } \\
\mathbf{1} \text { meter } \\
\text { [mrem/hr] }\end{array}$ \\
\hline 33.53 & 10.496 & 0.459 & 1.040 & 0.915 & 12.910 \\
\hline 70.13 & 15.924 & 0.495 & 1.043 & 1.230 & 18.692 \\
\hline 106.73 & 21.657 & 0.438 & 1.125 & 1.523 & 24.743 \\
\hline 143.33 & 25.824 & 0.353 & 1.220 & 1.768 & 29.165 \\
\hline 179.93 & 28.082 & 0.292 & 1.282 & 1.919 & 31.575 \\
\hline 216.53 & 28.296 & 0.258 & 1.317 & 2.021 & 31.892 \\
\hline 253.13 & 28.485 & 0.243 & 1.325 & 2.042 & 32.096 \\
\hline 289.73 & 27.062 & 0.243 & 1.307 & 2.008 & 30.621 \\
\hline 326.33 & 26.408 & 0.266 & 1.259 & 1.914 & 29.847 \\
\hline 362.93 & 24.686 & 0.308 & 1.159 & 1.741 & 27.894 \\
\hline 399.53 & 20.611 & 0.359 & 1.053 & 1.506 & 23.529 \\
\hline 436.13 & 15.125 & 0.411 & 0.885 & 1.206 & 17.627 \\
\hline 472.73 & 9.402 & 0.420 & 0.769 & 0.920 & 11.510 \\
\hline & & & & & \\
\hline
\end{tabular}


Table 9. Equivalent Dose Rate of a Single Cask Shielded by NBS 04 Concrete

\begin{tabular}{|r|r|r|r|r|r|}
\hline $\begin{array}{c}\text { Elevation } \\
\text { [cm] }\end{array}$ & $\begin{array}{c}\text { fission } \\
\text { product } \\
\text { gamma } \\
\text { dose at 1 } \\
\text { meter } \\
\text { [mrem/h] }\end{array}$ & $\begin{array}{c}\text { Co-60 } \\
\text { gamma } \\
\text { dose at 1 } \\
\text { meter } \\
\text { [mrem/h] }\end{array}$ & $\begin{array}{c}\text { neutron } \\
\text { dose at 1 } \\
\text { meter } \\
\text { [mrem/h] }\end{array}$ & $\begin{array}{c}\text { neutron } \\
\text { capture } \\
\text { gamma } \\
\text { dose at 1 } \\
\text { meter } \\
\text { [mrem/h] }\end{array}$ & $\begin{array}{c}\text { total dose at } \\
\mathbf{1} \text { meter } \\
\text { [mrem/hr] }\end{array}$ \\
\hline 33.53 & 13.185 & 0.513 & 2.402 & 1.520 & 17.619 \\
\hline 70.13 & 19.893 & 0.564 & 2.568 & 2.007 & 25.032 \\
\hline 106.73 & 25.740 & 0.494 & 2.859 & 2.469 & 31.562 \\
\hline 143.33 & 29.206 & 0.374 & 3.102 & 2.842 & 35.523 \\
\hline 179.93 & 30.980 & 0.303 & 3.279 & 3.105 & 37.666 \\
\hline 216.53 & 31.914 & 0.265 & 3.377 & 3.260 & 38.817 \\
\hline 253.13 & 33.178 & 0.262 & 3.365 & 3.310 & 40.115 \\
\hline 289.73 & 31.502 & 0.255 & 3.257 & 3.258 & 38.272 \\
\hline 326.33 & 28.726 & 0.262 & 3.098 & 3.091 & 35.176 \\
\hline 362.93 & 25.654 & 0.298 & 2.828 & 2.825 & 31.604 \\
\hline 399.53 & 21.238 & 0.364 & 2.433 & 2.431 & 26.465 \\
\hline 436.13 & 15.806 & 0.395 & 2.055 & 1.977 & 20.233 \\
\hline 472.73 & 10.032 & 0.381 & 1.753 & 1.473 & 13.640 \\
\hline & & & & & \\
\hline
\end{tabular}


Table 10. Equivalent Dose Rate of a Single Cask Shielded by Hanford Concrete (Dry)

\begin{tabular}{|r|c|r|r|r|r|}
\hline $\begin{array}{c}\text { Elevation } \\
\text { [cm] }\end{array}$ & $\begin{array}{c}\text { fission } \\
\text { product } \\
\text { gamma } \\
\text { dose at 1 } \\
\text { meter } \\
\text { [mrem/h] }\end{array}$ & $\begin{array}{c}\text { Co-60 } \\
\text { gamma } \\
\text { dose at 1 } \\
\text { meter } \\
\text { [mrem/h] }\end{array}$ & $\begin{array}{c}\text { neutron } \\
\text { dose at 1 } \\
\text { meter } \\
\text { [mrem/h] }\end{array}$ & $\begin{array}{c}\text { neutron } \\
\text { capture } \\
\text { gamma } \\
\text { dose at 1 } \\
\text { meter } \\
\text { [mrem/h] }\end{array}$ & $\begin{array}{c}\text { total dose at } \\
\mathbf{1} \text { meter } \\
\text { [mrem/hr] }\end{array}$ \\
\hline 33.53 & 22.114 & 1.205 & 4.374 & 2.767 & 30.461 \\
\hline 70.13 & 34.759 & 1.210 & 4.953 & 3.585 & 44.508 \\
\hline 106.73 & 47.983 & 1.034 & 5.820 & 4.355 & 59.192 \\
\hline 143.33 & 58.414 & 0.796 & 6.387 & 4.991 & 70.589 \\
\hline 179.93 & 63.930 & 0.634 & 6.702 & 5.455 & 76.721 \\
\hline 216.53 & 64.732 & 0.551 & 6.921 & 5.714 & 77.919 \\
\hline 253.13 & 63.159 & 0.531 & 6.926 & 5.808 & 76.424 \\
\hline 289.73 & 60.343 & 0.541 & 6.860 & 5.741 & 73.485 \\
\hline 326.33 & 59.341 & 0.546 & 6.611 & 5.439 & 71.937 \\
\hline 362.93 & 55.396 & 0.610 & 5.918 & 4.973 & 66.897 \\
\hline 399.53 & 46.983 & 0.716 & 5.213 & 4.294 & 57.206 \\
\hline 436.13 & 33.892 & 0.814 & 4.397 & 3.490 & 42.594 \\
\hline 472.73 & 20.413 & 0.824 & 3.629 & 2.630 & 27.495 \\
\hline & & & & & \\
\hline
\end{tabular}

\subsection{Comparison of Dose Components for Various Compositions at a Fixed Density}

Based upon the initial results of comparing the four compositions, it is beneficial to perform a direct comparison of each component of the total dose rate for compositions at a fixed density. A high density version of standard concrete, NBS 03 concrete, and NBS 04 concrete were all compared at a density of $2.35 \frac{\mathrm{g}}{\mathrm{cm}^{3}}$. The fission product dose rates are compared in Table 11, the dose rates of the activation structure in Table 12, the neutron dose rates in Table 13, and the dose from gamma rays produced by neutron capture in Table 14. Changes in the dose rate from the activated structural components, which are being treated as a ${ }^{60} \mathrm{Co}$ source that produces a small number of relatively high 
energy gamma rays, experience small changes that could be neglected due to uncertainty of calculations, however, in all other cases, it is evident that the difference in composition generates a significant change in the dose rate. The difference between NBS 03 and either NBS 04 or the standard composition was typically on the order of $20 \%$ for the dose rate from gamma rays produced by fission products or the activated structural components, approximately $70 \%$ for the dose produced by gamma rays produced by neutron capture, and on the order of $100 \%$ for the dose from the neutrons themselves.

While there are differences, the standard composition behaves similarly to the NBS 04 composition due to similarities in composition. In particular, the standard composition is closer to NBS 04 than NBS 03 in the level of hydrogen, a low atomic number material important in neutron scattering, as well as oxygen and silicon. The increased level of hydrogen in NBS 03 contributes significantly to its lower overall dose rate by reducing neutron penetration and, consequently, generating the neutron capture gamma rays. Overall, these results indicate that, even at the same density, the specific composition will have a significant effect upon dose rates from both gamma rays and neutrons. Given that the precise composition will vary based upon the exact mixing and curing conditions, as well as the commercial brand of concrete utilized by the end user of the cask, this can play a significant role in the dose levels at the storage site. Provided the cask can handle the structural stresses of a heavier material, it may be necessary to utilize higher density, specialized shielding concrete compositions or, alternately, to 
establish a larger area of exclusion to account for the uncertainties this can generate when estimating dry cask dose rate levels.

Table 11. Equivalent Dose Rate from Fission Products for Various Compositions

\begin{tabular}{|c|c|c|c|}
\hline Elevation [cm] & $\begin{array}{c}\text { Dose at } 1 \text { meter } \\
\text { NBS 03 Concrete } \\
{[\mathrm{mrem} / \mathrm{h}]} \\
\end{array}$ & $\begin{array}{c}\text { Dose at } 1 \text { meter } \\
\text { NBS 04 Concrete } \\
{[\mathrm{mrem} / \mathrm{h}]}\end{array}$ & $\begin{array}{c}\text { Dose at } 1 \text { meter } \\
\text { with Standard } \\
\text { Concrete }(\text { Density } \\
\left.=2.35 \mathrm{~g} / \mathrm{cm}^{\wedge} 3\right) \\
{[\mathrm{mrem} / \mathrm{h}]}\end{array}$ \\
\hline 33.53 & 10.496 & 13.185 & 12.203 \\
\hline 70.13 & 15.924 & 19.893 & 19.059 \\
\hline 106.73 & 21.657 & 25.740 & 25.176 \\
\hline 143.33 & 25.824 & 29.206 & 29.024 \\
\hline 179.93 & 28.082 & 30.980 & 30.128 \\
\hline 216.53 & 28.296 & 31.914 & 28.922 \\
\hline 253.13 & 28.485 & 33.178 & 29.807 \\
\hline 289.73 & 27.062 & 31.502 & 28.401 \\
\hline 326.33 & 26.408 & 28.726 & 26.513 \\
\hline 362.93 & 24.686 & 25.654 & 23.280 \\
\hline 399.53 & 20.611 & 21.238 & 19.538 \\
\hline 436.13 & 15.125 & 15.806 & 14.056 \\
\hline 472.73 & 9.402 & 10.032 & 8.805 \\
\hline
\end{tabular}


Table 12. Equivalent Dose Rate from Activated Structures for Various Compositions

\begin{tabular}{|c|c|c|c|}
\hline Elevation [cm] & $\begin{array}{c}\text { Dose at } 1 \text { meter } \\
\text { NBS 03 Concrete } \\
{[\mathrm{mrem} / \mathrm{h}]}\end{array}$ & $\begin{array}{c}\text { Dose at } 1 \text { meter } \\
\text { NBS 04 Concrete } \\
{[\mathrm{mrem} / \mathrm{h}]}\end{array}$ & $\begin{array}{c}\text { Dose at } 1 \text { meter } \\
\text { with Standard } \\
\text { Concrete }(\text { Density } \\
\left.=2.35 \mathrm{~g} / \mathrm{cm}^{\wedge} 3\right) \\
{[\mathrm{mrem} / \mathrm{h}]} \\
\end{array}$ \\
\hline 33.53 & 0.459 & 0.513 & 0.504 \\
\hline 70.13 & 0.495 & 0.564 & 0.556 \\
\hline 106.73 & 0.438 & 0.494 & 0.488 \\
\hline 143.33 & 0.353 & 0.374 & 0.387 \\
\hline 179.93 & 0.292 & 0.303 & 0.315 \\
\hline 216.53 & 0.258 & 0.265 & 0.272 \\
\hline 253.13 & 0.243 & 0.262 & 0.254 \\
\hline 289.73 & 0.243 & 0.255 & 0.250 \\
\hline 326.33 & 0.266 & 0.262 & 0.251 \\
\hline 362.93 & 0.308 & 0.298 & 0.282 \\
\hline 399.53 & 0.359 & 0.364 & 0.343 \\
\hline 436.13 & 0.411 & 0.395 & 0.387 \\
\hline 472.73 & 0.420 & 0.381 & 0.388 \\
\hline
\end{tabular}


Table 13. Equivalent Dose Rate from Neutrons for Various Compositions

\begin{tabular}{|r|r|r|r|}
\hline Elevation [cm] & $\begin{array}{c}\text { Dose at 1 meter } \\
\text { NBS 03 Concrete } \\
\text { [mrem/h] }\end{array}$ & $\begin{array}{c}\text { Dose at 1 meter } \\
\text { Dose at 1 meter } \\
\text { NBS 04 Concrete } \\
\text { [mrem/h] }\end{array}$ & $\begin{array}{c}\text { with Standard } \\
\text { Concrete (Density } \\
\mathbf{2 . 3 5} \mathbf{g} / \mathbf{c m} \text { ( 3) } \\
\text { [mrem/h] }\end{array}$ \\
\hline 33.53 & 1.040 & 2.402 & 3.267 \\
\hline 70.13 & 1.043 & 2.568 & 3.548 \\
\hline 106.73 & 1.125 & 2.859 & 3.986 \\
\hline 143.33 & 1.220 & 3.102 & 4.401 \\
\hline 179.93 & 1.282 & 3.279 & 4.698 \\
\hline 216.53 & 1.317 & 3.377 & 4.857 \\
\hline 253.13 & 1.325 & 3.365 & 4.897 \\
\hline 289.73 & 1.307 & 3.257 & 4.815 \\
\hline 326.33 & 1.259 & 3.098 & 4.513 \\
\hline 362.93 & 1.159 & 2.828 & 4.104 \\
\hline 399.53 & 1.053 & 2.433 & 3.478 \\
\hline 436.13 & 0.885 & 2.055 & 2.769 \\
\hline 472.73 & 0.769 & 1.753 & 2.181 \\
\hline & & & \\
\hline
\end{tabular}


Table 14. Equivalent Dose Rate from Gammas Produced by Neutron Capture for Various Compositions

\begin{tabular}{|c|c|c|c|}
\hline Elevation $[\mathrm{cm}]$ & $\begin{array}{c}\text { Dose at } 1 \text { meter } \\
\text { NBS 03 Concrete } \\
{[\mathrm{mrem} / \mathrm{h}]}\end{array}$ & $\begin{array}{c}\text { Dose at } 1 \text { meter } \\
\text { NBS 04 Concrete } \\
{[\mathrm{mrem} / \mathrm{h}]}\end{array}$ & $\begin{array}{c}\text { Dose at } 1 \text { meter } \\
\text { with Standard } \\
\text { Concrete }(\text { Density } \\
\left.=2.35 \mathrm{~g} / \mathrm{cm}^{\wedge} 3\right) \\
{[\mathrm{mrem} / \mathrm{h}]}\end{array}$ \\
\hline 33.53 & 0.915 & 1.520 & 1.988 \\
\hline 70.13 & 1.230 & 2.007 & 2.612 \\
\hline 106.73 & 1.523 & 2.469 & 3.196 \\
\hline 143.33 & 1.768 & 2.842 & 3.668 \\
\hline 179.93 & 1.919 & 3.105 & 3.995 \\
\hline 216.53 & 2.021 & 3.260 & 4.186 \\
\hline 253.13 & 2.042 & 3.310 & 4.245 \\
\hline 289.73 & 2.008 & 3.258 & 4.182 \\
\hline 326.33 & 1.914 & 3.091 & 3.996 \\
\hline 362.93 & 1.741 & 2.825 & 3.623 \\
\hline 399.53 & 1.506 & 2.431 & 3.118 \\
\hline 436.13 & 1.206 & 1.977 & 2.532 \\
\hline 472.73 & 0.920 & 1.473 & 1.915 \\
\hline
\end{tabular}

\subsection{Comparison of Dose Components at Various Densities for a Single Composition}

In addition to comparing the impact of variations in concrete composition at a fixed density, it was also necessary to compare the effects of variations in density when the specific composition is fixed. These studies assume that the basic aggregate remains the same, but that minor differences in the mixing and curing processes have resulted in minor variation in density. This study also reflects the uncertainty in specific densities listed in the material compendium to generate the nominal values. The standard concrete composition was varied by $\pm 0.1 \frac{\mathrm{g}}{\mathrm{cm}^{3}}$, and results were tabulated for each component of 
the total dose rate. Figure 7 displays the trends for the gamma rays produced by fission products, Figure 8 shows them for the dose rates due to the activated structures, Figure 9 reveals the neutron dose rate distributions, and Figure 10 reveals the dose rates due to gamma rays produced by neutron capture. These results indicate, as expected, that dose rate from all the sources decreases significantly with even minor increases in density due to the increase in macroscopic cross sections or attenuation coefficients, which are directly related to number density. It also indicates that the gamma ray dose, from the fuel and the activated structural materials, is influenced more than the dose rate from neutrons or the gamma rays produced by neutron capture. The gamma dose rates reduced by a factor of approximately 2 when transitioning from a density of $2.15 \frac{\mathrm{g}}{\mathrm{cm}^{3}}$ to $2.35 \frac{\mathrm{g}}{\mathrm{cm}^{3}}$, however, the neutron and gamma rays from neutron capture were only reduced by a factor of approximately 1.5. This is due to the fact that Compton scattering depends directly upon number density and is only minimally affected by the material composition, but neutron shielding is more complex and the dose rate from gamma rays produced by neutron capture is proportional to the neutron reactions. These results indicate that, while the composition of the concrete is important, even minor variations in density can have a far more drastic impact on the effectiveness of shielding, since the majority of the dose comes from the gamma rays produced by fission products. 


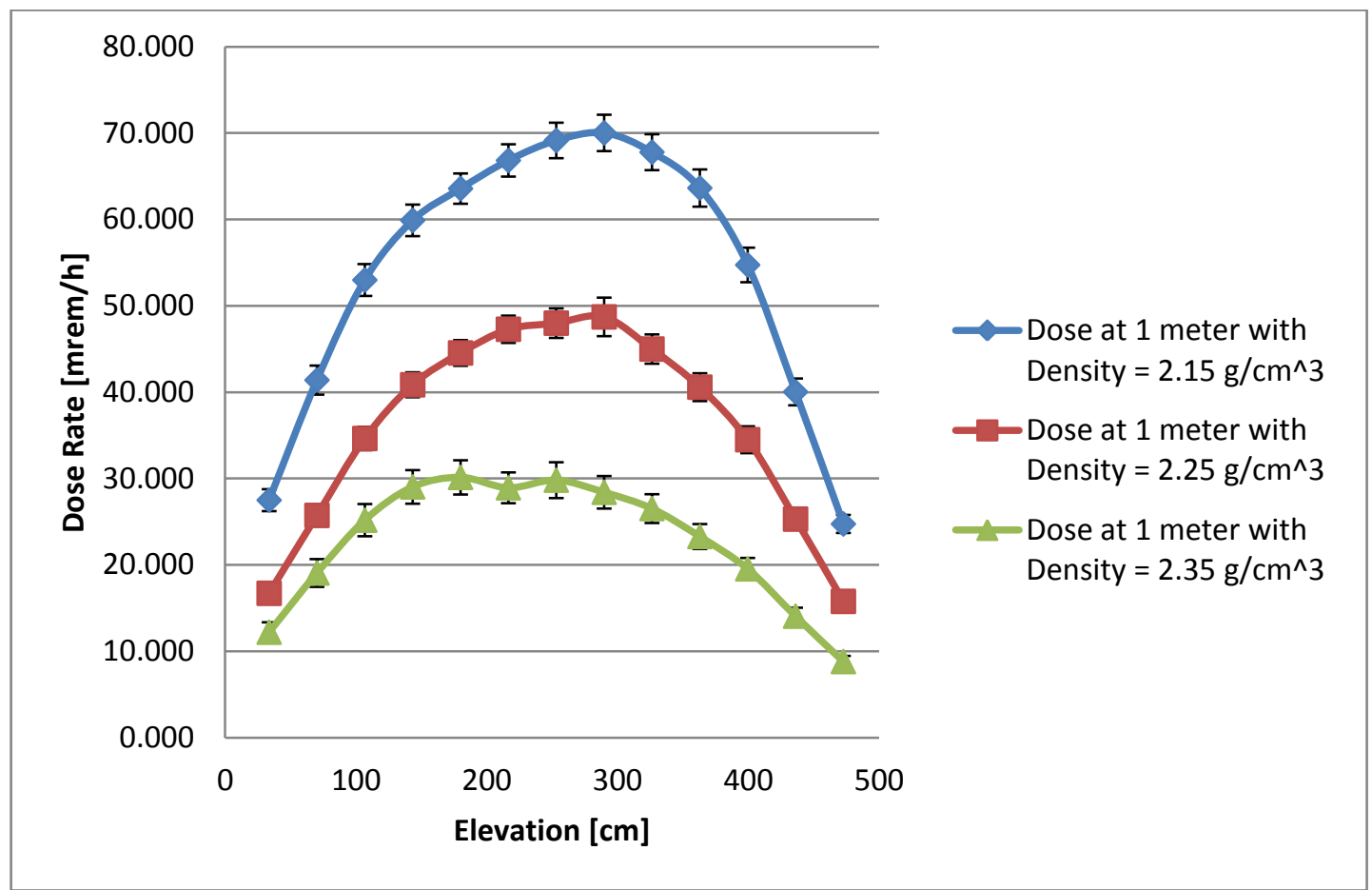

Figure 7. Equivalent dose rate from fission products as a function of height for various densities of standard concrete. 


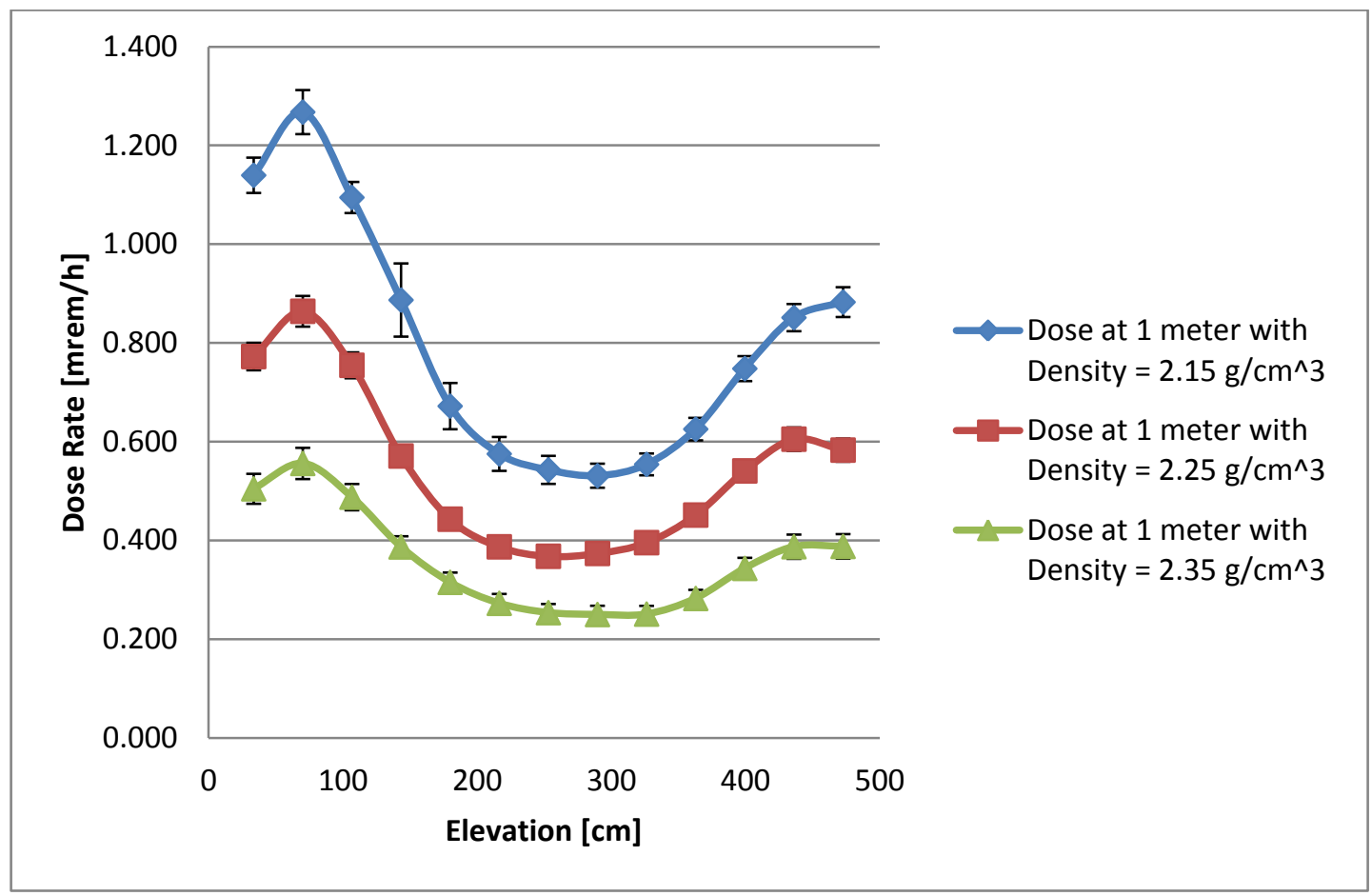

Figure 8. Equivalent dose rate from activated structures as a function of height for various densities of standard concrete. 


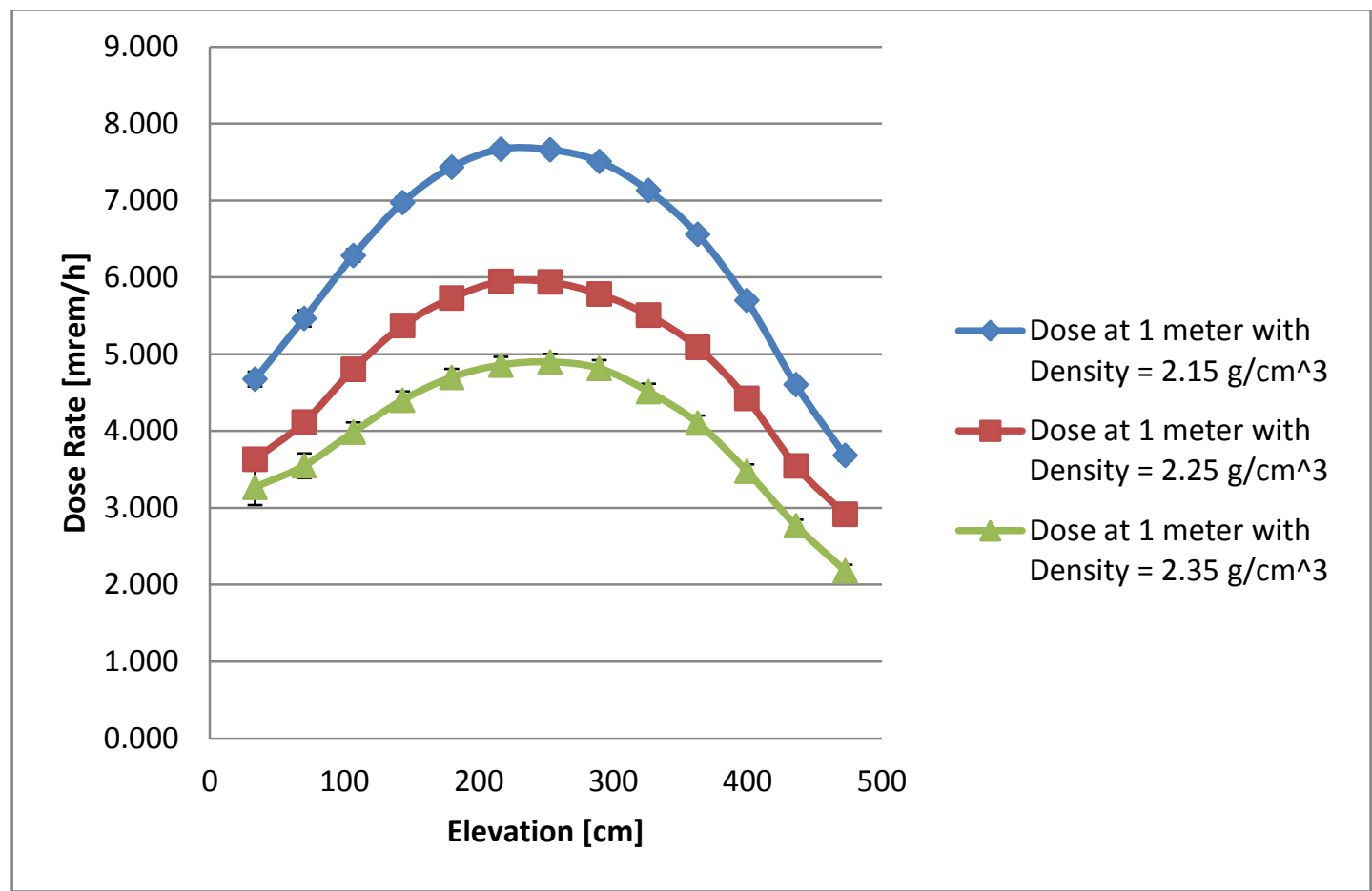

Figure 9. Equivalent dose rate from neutrons as a function of height for various densities of standard concrete. 


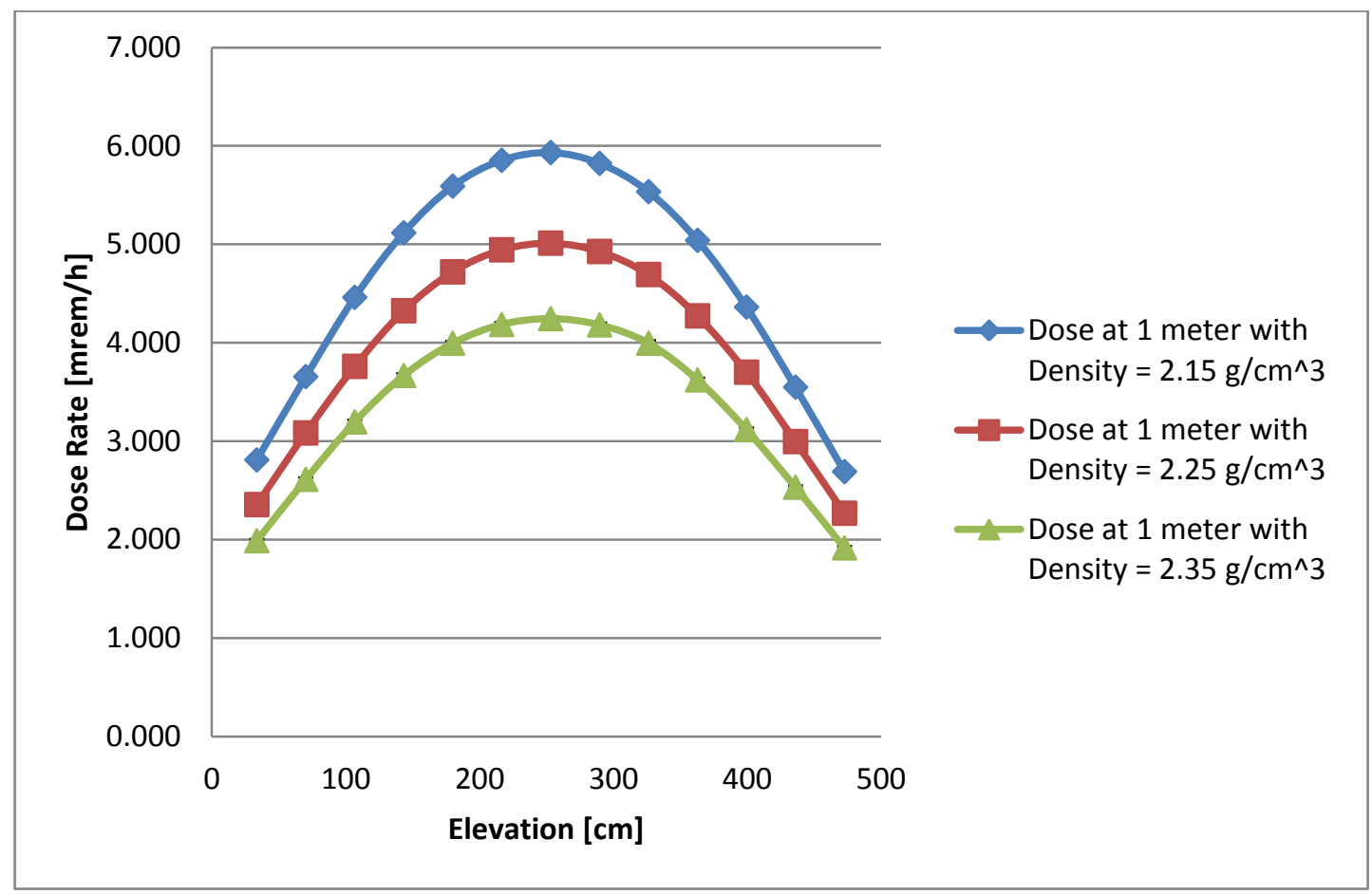

Figure 10. Equivalent dose rate from gammas produced by neutron capture as a function of height for various densities of standard concrete.

\subsection{Comparison of Three-Years-Cooled and Five-Years-Cooled Results}

In addition to determining the effect of varying composition and density upon a source that is kept constant, it is also significant to analyze how variations in the source term influence the dose rate, and to determine how this behavior varies between the different concrete compositions. In addition to the normal cases where three-yearscooled fuel was analyzed, a set of cases that utilized five-years-cooled fuel was also performed. The decay of neutron due to this two year difference was relatively minor and can be ignored for this analysis, and while the change in the ${ }^{60} \mathrm{Co}$ source magnitude is relatively significant, its energy distribution is not, and its relatively small size means 
that the change can be considered negligible. Therefore, only the dose rate due to the fission product gamma ray source was analyzed. Figure 11 shows the difference between the three-years-cooled and five-years-cooled cases for the standard concrete composition, Figure 12 shows the NBS 03 composition, Figure 13 reveals the NBS 04 composition results, and Figure 14 displays the Hanford composition results. In general, all dose rates dropped approximately $40 \%$. While there were minor variations between compositions and at different axial levels, none reached the level of statistical significance. Based upon these results, the change in energy distribution due to the additional decay was not significant enough to alter the relative effectiveness of a given concrete composition, however, the drop in absolute dose level may make additional concrete compositions acceptable to vendors for the five-year-fuel as dose rates drop below safety thresholds. 


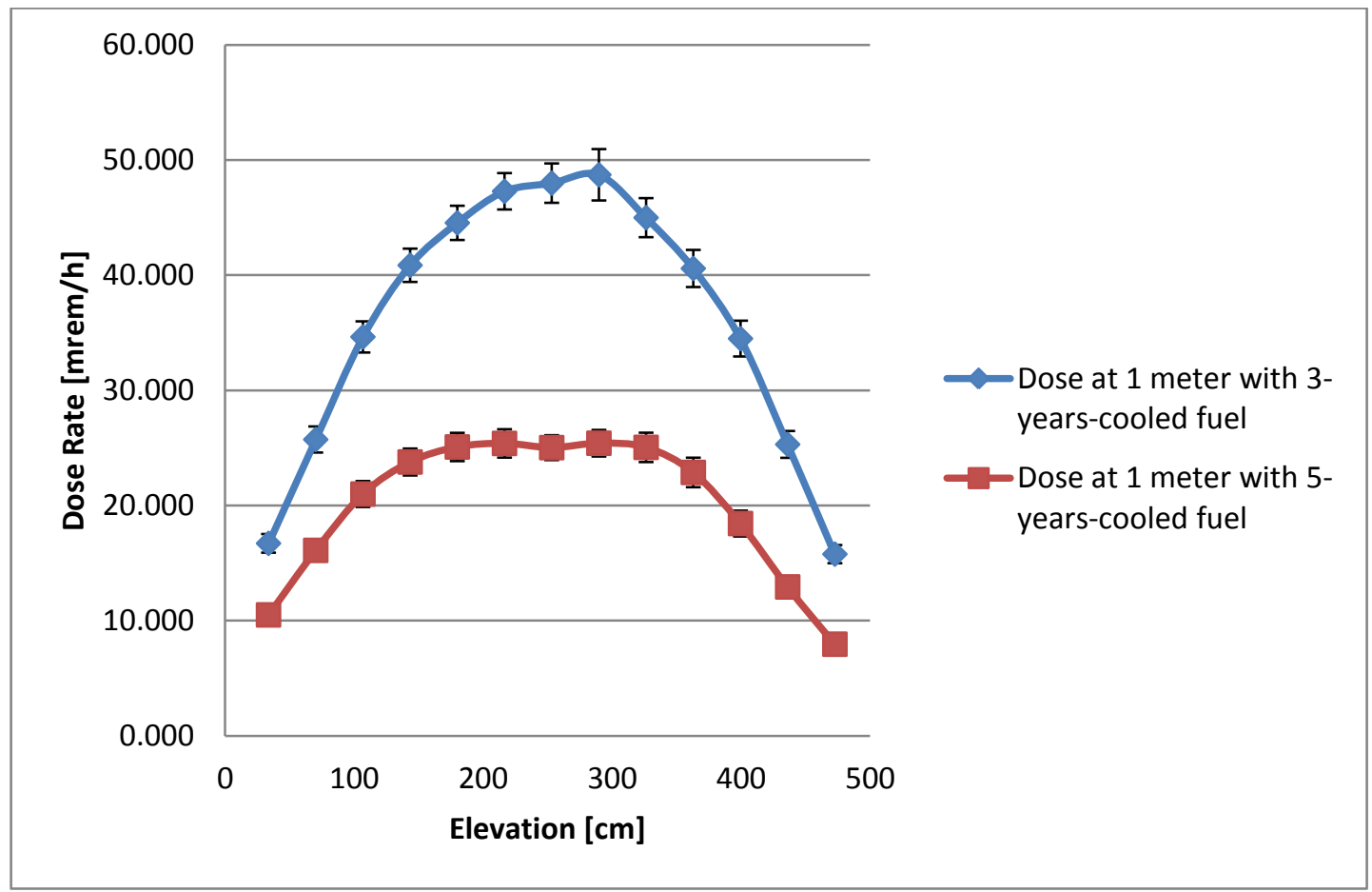

Figure 11. Equivalent dose rate from fission products as a function of height for threeyears-cooled and five-years-cooled fuel with standard concrete. 


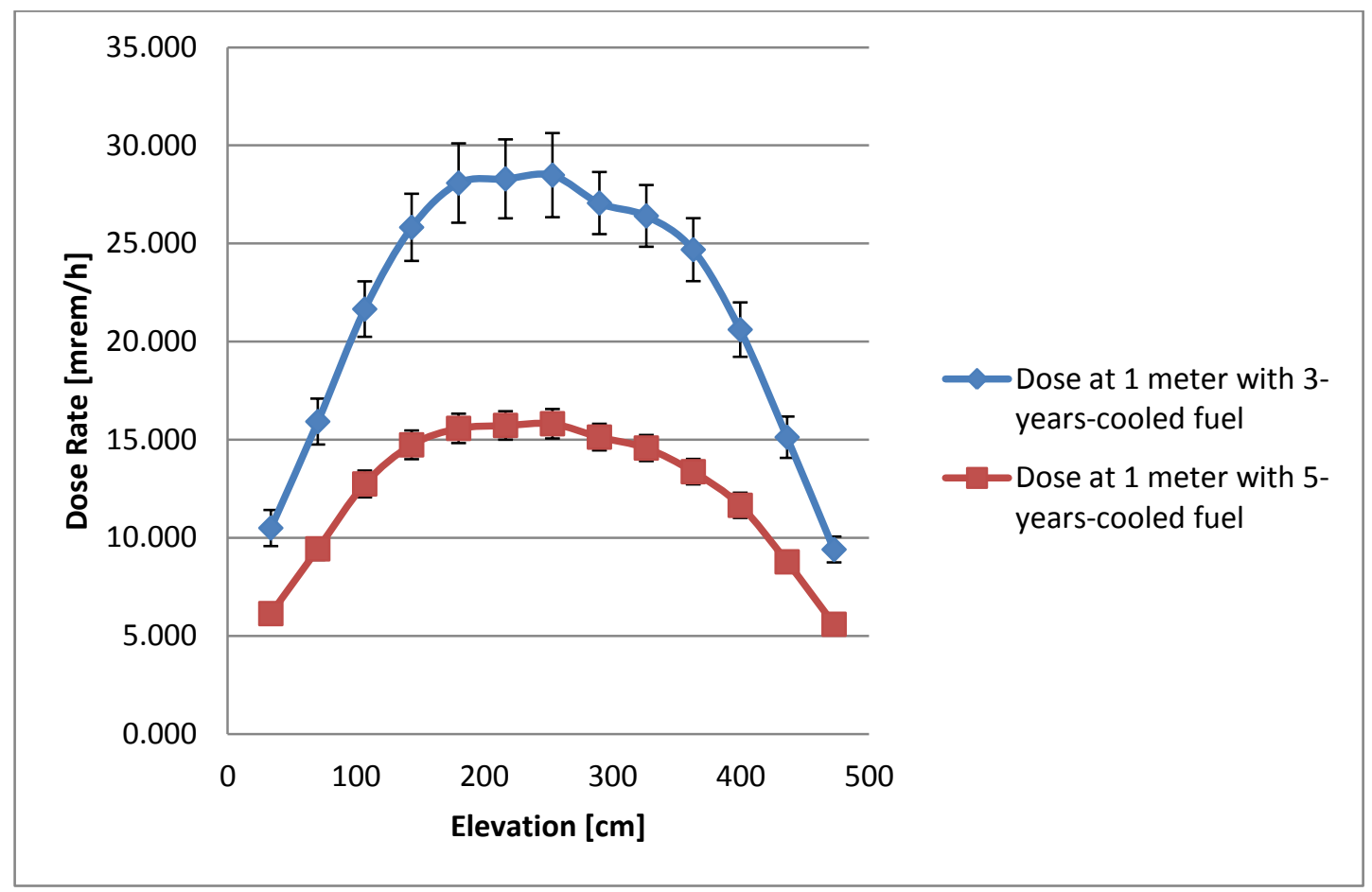

Figure 12. Equivalent dose rate from fission products as a function of height for threeyears-cooled and five-years-cooled fuel with NBS 03concrete. 


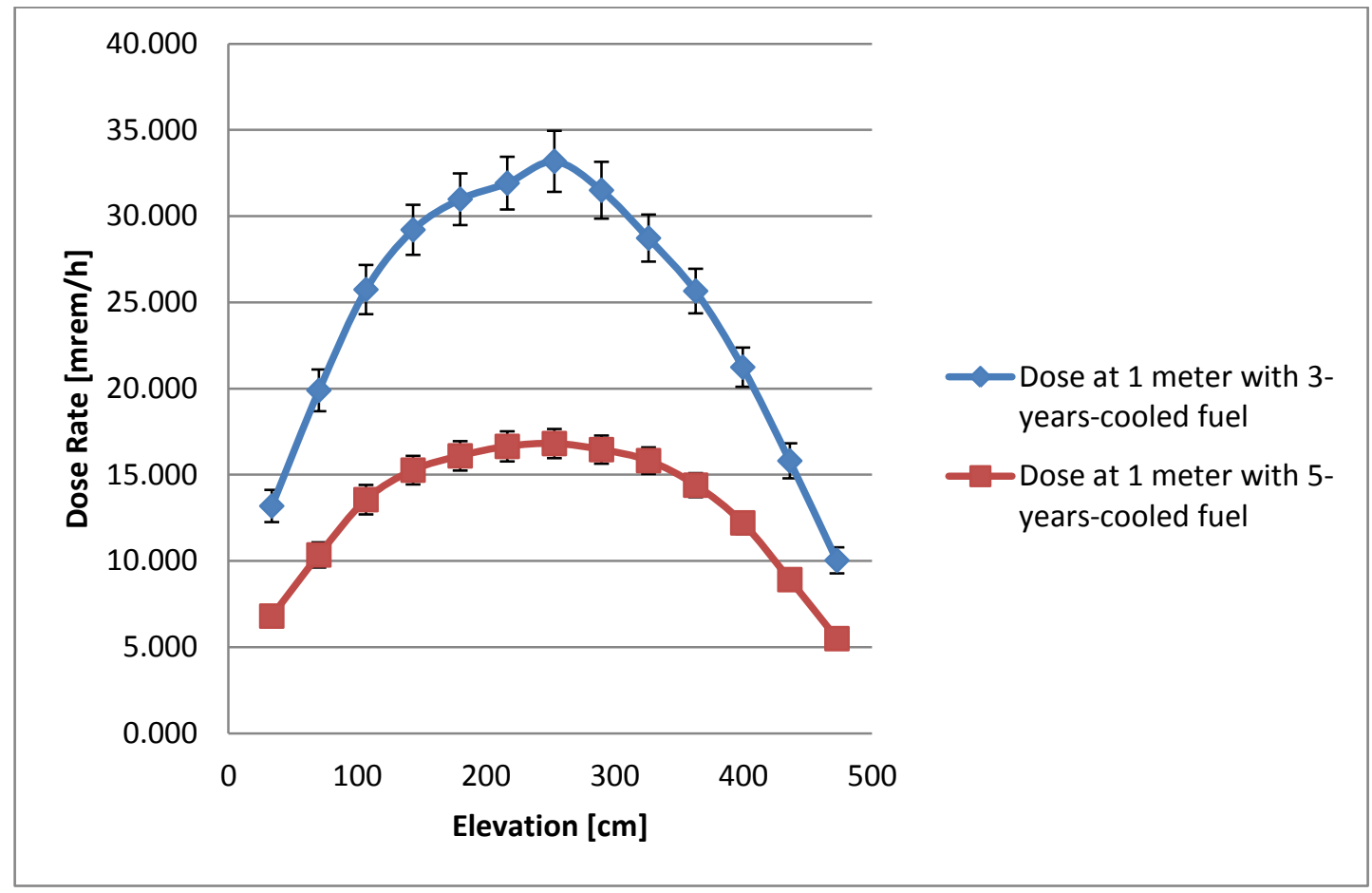

Figure 13. Equivalent dose rate from fission products as a function of height for threeyears-cooled and five-years-cooled fuel with NBS 04 concrete. 


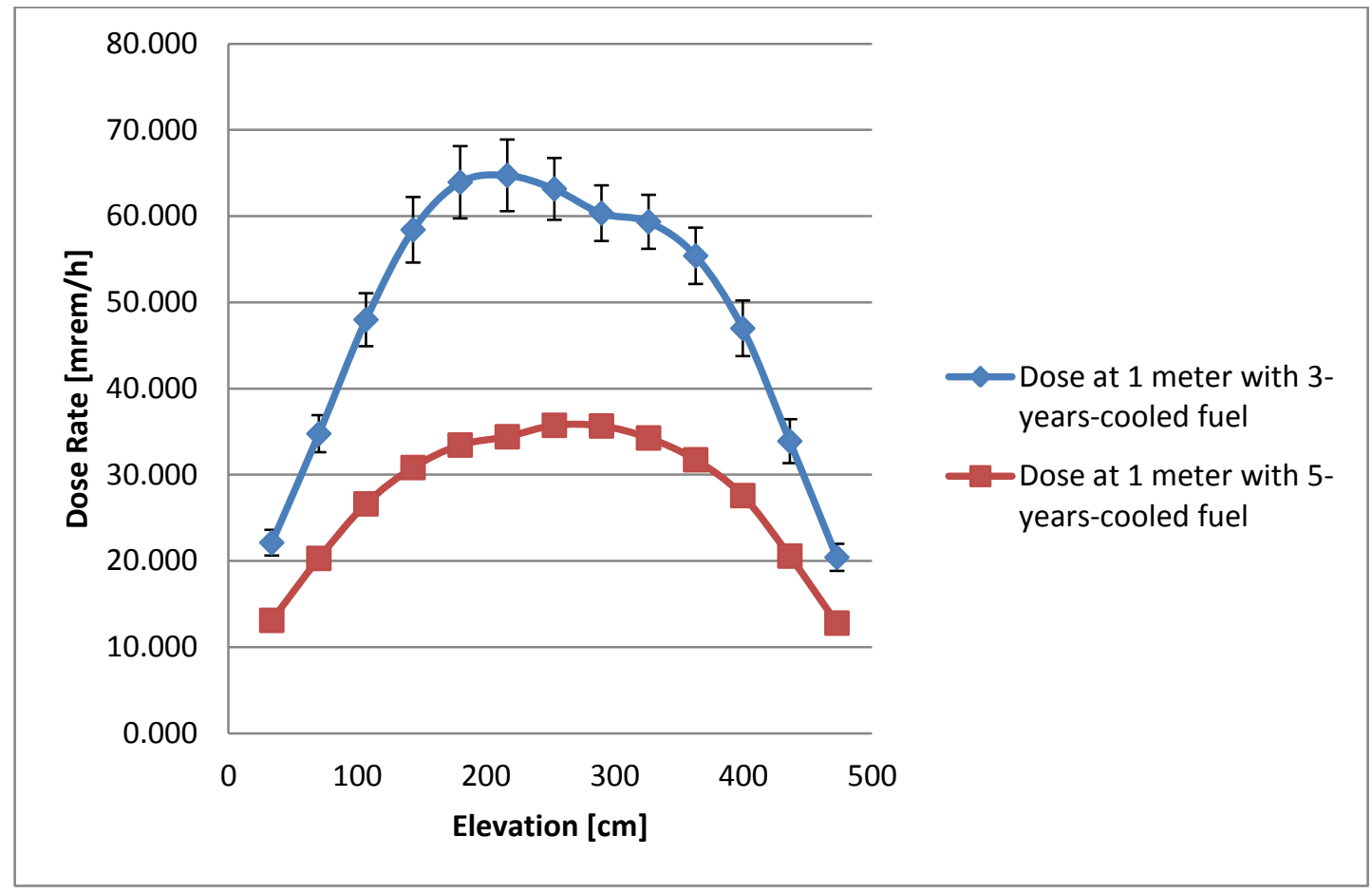

Figure 14. Equivalent dose rate from fission products as a function of height for threeyears-cooled and five-years-cooled fuel with Hanford concrete. 


\section{CONCLUSIONS}

This research confirms that variations in concrete density and composition that can be expected among commercial concrete suppliers can have a significant effect upon the shielding characteristics of a system. The effects of density variation, which can come from a variety of sources including increased air or water content, were very clear, as expected, and had the strongest impact on a system by far. Even when density levels were the same, however, variations between different commercial specifications or laboratory definitions were significant. The results indicated that variations had a moderate effect on the dose from gamma rays produced by the fission products and the activated assembly components, but a much larger impact on the dose from neutrons and gamma rays produced from neutron capture, though the exact level of this difference will depend on the specific compositions studied. The hydrogen content of the concrete was an influential factor, but other differences also influenced the final dose values. While the fact that the dose contribution from the gamma rays produced by fission products are a large part of the total dose values, contributing on the order of $70 \%$ of the dose for all cases using three-years-cooled fuel, prevented this composition variance from dominating shielding considerations, it is still important. The minor variations in energy spectra with additional decay do not appear to significantly impact these results, as the decrease when comparing three-year-cooled and five-year-cooled sources was relatively uniform when comparing different compositions. This indicates that the results from these test cases should be applicable in general to similar sources and cask 
geometries, without requiring significant variations for decay time. Overall, the results indicate that the allowable 6 to $8 \%$ variations in concrete characteristics, as well of the variation in commercial compositions and specifications, can generate significant differences in dose rates. Even with a specific brand specified by the vendor, the variations in climate and the mixing methods on site can be significant, and homogenous mixture testing is not necessarily feasible in the environment of the dry storage casks. Therefore, end users of shielded casks should take these potential uncertainties into account when determining safety factors governing the size of exclusion zones and the allowable time in storage cask presence, while vendors may wish to specify how to insure the users can obtain a consistent concrete composition above a minimum density value, either through a detailed process or increased use of heavier shielding concrete mixtures. 


\section{REFERENCES}

1. Disposal Subcommittee Report to the Full Commission, Blue Ribbon

Commission on America's Nuclear Future, Washington (2012),

<http://cybercemetery.unt.edu/archive/brc/20120620220845/http://brc.gov/sites/d

efault/files/documents/disposal_report_updated_final.pdf>, January 26, 2013.

2. JAMES D. WERNER, U.S. Spent Nuclear Fuel Storage, Congressional Research Service, Washington D. C. (2012), <http://www.fas.org/sgp/crs/misc/R42513.pdf>, January 26, 2013.

3. "Dry Cask Storage", Nuclear Regulatory Commission, Washington D.C. (December 2012), <http://www.nrc.gov/waste/spent-fuel-storage/dry-caskstorage.html>, January 26, 2013.

4. ED LYMAN, “Pools May be 'Adequate', But Dry Casks are Safer”, Union of Concerned Scientists (July 2012), <http://allthingsnuclear.org/pools-may-beadequate-but-dry-casks-are-safer/>, January 26, 2013.

5. "Part 72- License Requirements for the Independent Storage of Spent Nuclear Fuel, High-Level Radioactive Waste, and Reactor-Related Greater than Class C Waste”, Nuclear Regulatory Commission, Washington D.C. (2013), <http://www.nrc.gov/reading-rm/doc-collections/cfr/part072/full-text.html>, January 26, 2013. 
6. SEAN M. MCDEAVITT et al., IRP- Fuel Aging in Storage and Transportation (FAST): Accelerated Characterization and Performance Assessment of the Used Nuclear Fuel Storage System, Texas A\&M University, College Station (2011).

7. A.MALLIAKOS, “A Pilot Probabilistic Risk Assessment of a Dry Cask Storage System at a Nuclear Power Plant”, Nuclear Regulatory Commission, Washington D.C. (March 2007), <http://www.nrc.gov/reading-rm/doccollections/nuregs/staff/sr1864/sr1864.pdf>, January 26, 2013.

8. S.J. STANKOVIC et al., "Gamma Radiation Absorption Characteristics of Concrete with Components of Different Material Types", Conference of the Materials Research Society of Serbia, 117 (2010), < http://przyrbwn.icm.edu.pl/APP/PDF/117/a117z520.pdf>, January 26, 2013.

9. ALFREDO LORENTE et al., "Neutron Shielding Properties of a New HighDensity Concrete", Homirad (2008), <http://oa.upm.es/4596/1/INVE_MEM_2008_61569.pdf>, January 26, 2013.

10. CHERIA F.FERRARIS, "Concrete Mixing Methods and Concrete Mixers: State of the Art", Journal of Research of the National Institute of Standards and Technology, 106, 391-399 (2001), <http://nvlpubs.nist.gov/nistpubs/jres/106/2/j62fer.pdf>, January 26, 2013.

11. "List of Approved Spent Fuel Storage Casks: HI-STORM 100, Revision 8", Nuclear Regulatory Commission, Washington D.C. (2012), <https://www.federalregister.gov/articles/2012/04/25/2012-9834/list-ofapproved-spent-fuel-storage-casks-hi-storm-100-revision-8>, January 26, 2013. 
12. RJ MCCONN Jr. et al., Compendium of Material Composition Data for Radiation Transport Monitoring, Pacific Northwest National Laboratory (March 2011), <http://www.pnnl.gov/main/publications/external/technical_reports/pnnl15870rev1.pdf>, January 26, 2013.

13. X-5 MONTE CARLO TEAM, MCNP-A General Monte Carlo N-Particle Transport Code, Version 5, LA-UR-03-1987, Los Alamos National Lab (2003), Private Communication.

14. "Radiation Source Terms (DBD-ME-025)," Comanche Peak Nuclear Power Plant, Rev. 10 (2012), Private Communication.

15. Final Safety Analysis Report for the HI-STORM 100 Cask System, Holtec International, Rev 9 (Feb 2010), Private Communication.

16. Staff Evaluation of Holtec Design for Portland General Electric's Independent Spent Nuclear Fuel Storage Installation (ISFSI), Oregon Office of Energy (September 2002), <http://www.oregon.gov/energy/Siting/docs/TRO/Holtec.PDF>, January 26, 2013.

17. “US-APWR”, Mitsubishi Heavy Industries Ltd. (June 2007), <http://www.ne.doe.gov/np2010/pdfs/3\%20\%20USAPWR\%20Fuel\%20and\%20Core.pdf>, January 26, 2013.

18. "National Building Specifications”, Royal Institute of British Architects (2013), <http://www.thenbs.com/index.asp>, January 26, 2013. 
19. “Concrete”, Hanford Ready Mix (2012), <http://hanfordreadymix.com/wordpress/?page_id=44>, January 26, 2013. 